\title{
The site of Leki Wakik, Manatuto District, Timor-Leste
}

\author{
Jack N. Fenner, Mirani Litster, Tim Maloney, Tse Siang Lim, \\ Stuart Hawkins, Prue Gaffey, Sally Brockwell, Andrew McWilliam, \\ Sandra Pannell, Richard C. Willan and Sue 0'Connor
}

\section{Introduction}

Leki Wakik is a large hilltop site with several large stone walls and circular stone arrangements located within the Manatuto district in the central region of Timor-Leste. It is similar to other hilltop sites in the area whose function and occupation time frame have been subject to debate (e.g. Lape and Chao 2008; O'Connor et al. 2012). In August 2011, a team from The Australian National University (ANU) supported by Timorese workers mapped the site and excavated five test pits intended to assess site use and occupation time frame. A substantial artefact assemblage was recovered that includes lithics, earthenware pottery, ceramics and faunal remains, which provides evidence of the use of the site and the surrounding landscape and, particularly, whether unusual circular stone arrangements demarcate special activity or occupation areas. A series of radiocarbon dates from an unusual area surrounded on three sides by large stone walls provide chronological context for the site.

We begin by discussing Leki Wakik's location within the landscape and its general layout and surface configuration. We then review historical and ethnological information about the site. Subsequent sections describe our excavation and analysis methods, followed by a detailed review of the results, including excavation pit stratigraphy and associated chronology (where available), and the cultural material assemblage of lithics, earthenware, tradeware ceramics, invertebrate faunal remains (mostly mollusc shell) and vertebrate faunal remains. We then use this information to characterise the site, beginning by identifying patterns that span multiple artefact classification types and continuing with a consideration of whether Leki Wakik should be classified as a fortified site in the context of other Timor-Leste fortified sites. The concluding section summarises our assessment of the site.

\section{Site location and layout}

Leki Wakik is located near the eastern border of Manatuto district in eastern Timor-Leste (Figure 5.1). The Banda Sea coastline is approximately $750 \mathrm{~m}$ to the north of the site, while the Laleia River is about $500 \mathrm{~m}$ to the east. 


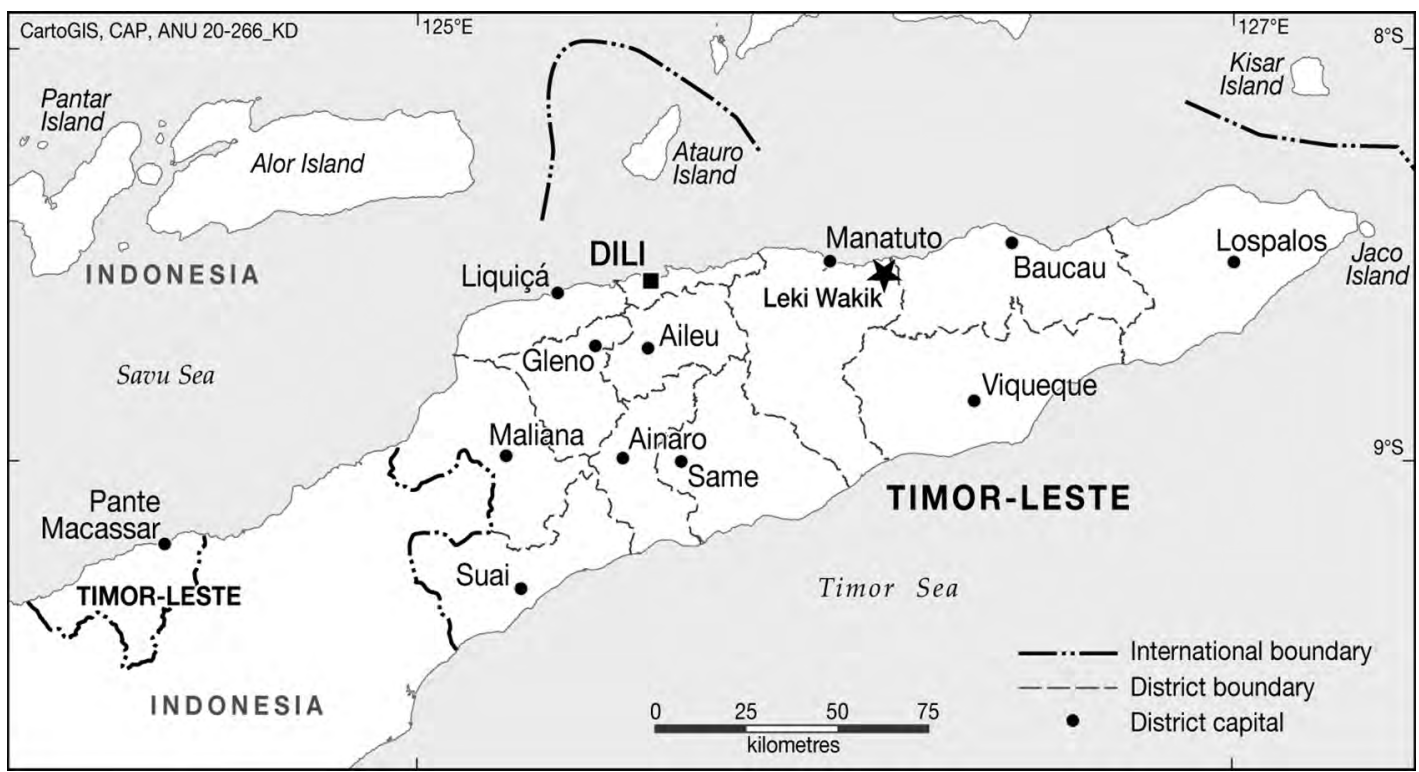

Figure 5.1. Timor-Leste map showing the location of Leki Wakik.

Source: CartoGIS ANU, modified by Jack Fenner.

Taking the natural hill slope edges as site boundaries, Leki Wakik covers about 39,000 $\mathrm{m}^{2}$ (Figure 5.2). This enormous area appears to be partitioned into three or four sectors; most notably, stone walls partition off arms of the site in the northwest and northeast. If these arms are excluded, the central area covers about $31,000 \mathrm{~m}^{2}$ and includes a large, very flat area in the north and a smaller southern area that generally slopes gently down to the northeast. The slope is most noticeable starting just to the west of the datum (Figure 5.2), but even within that area the slope is less than 10 degrees. It is unclear whether the site occupants would have considered the southern portion to be a separate area from the northern three-quarters of the site, but both portions include stone circles, which suggests that the site at least extends across the entire central area.

While slopes outside the site were not measured, site boundaries shown as thick black lines in Figure 5.2 mark areas where the land slopes steeply down outside the site. In most of these areas, it is possible but difficult to walk directly up the slope. The northern edge was not precisely mapped due to modern vegetation obstructions, but the dotted line is a reasonable approximation; the slope outside the site is steep in this area as well. The perimeter marked in purple is considered moderate slope; an adult can walk directly up the slope outside the site with moderate effort. Similarly, the low slope area to the west of the site can be walked with little effort.

There are four prominent stone walls extant within the site: two large, partially collapsed walls that partition off the northeastern and northwestern arms of the site, a large wall that extends in from the site boundary in the southeast and partially encloses a flat area, and a small, low wall in the southern portion with no apparent function. About $7.5 \mathrm{~m}$ south of the latter wall is an alignment of single stones running roughly parallel to it for about half its length; this could be a recent feature or it could be the surface remnant of a larger wall. 


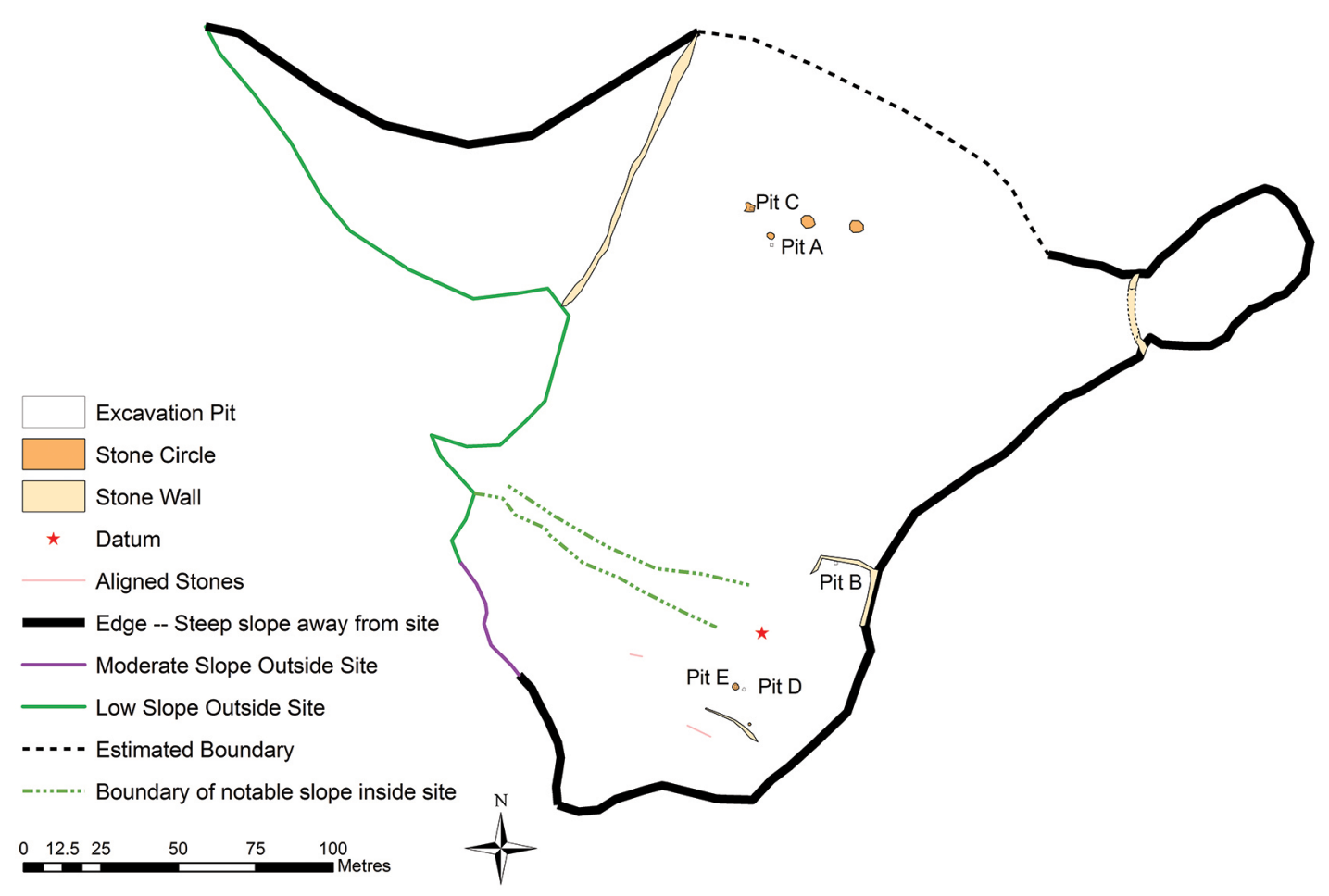

Figure 5.2. Leki Wakik site plan view.

Source: Jack Fenner.

At first, the two prominent walls that partition the site's arms in the north appear to be defensive in nature. They are thick walls; while generally a maximum of about $1 \mathrm{~m}$ high today, they originally would have been substantially higher. Neither wall contains a visible gap or entryway. The defensive nature of the walls, however, becomes unclear when considering the overall site layout. The northeast wall partitions off a relatively small area that otherwise is bounded by some of the steepest slopes around the site. The wall thus protects the northeast arm from the rest of the site (or vice versa) rather than providing protection from a force attacking the site from outside. More significantly, the northwest wall peters out in an area with low slope; a force coming from the west could easily go around it. We will revisit this issue when discussing site function below. We also note that there are several very large prickly pear cacti (Opuntia elatior) standing over $2 \mathrm{~m}$ tall growing along the wall in the northwest, which present formidable though geographically constrained barriers. This invasive weed, however, was introduced to Timor-Leste in the early twentieth century (McWilliam 2000:465) and thus was not present during most of Leki Wakik's occupation.

There are six roughly circular piles of stone within Leki Wakik: four clustered in the central north of the site and two in the southeast (Figure 5.2). In the north, the two westernmost stone piles are 2.0 to $2.6 \mathrm{~m}$ in diameter while the two eastern piles are larger, at 4.0 to $4.5 \mathrm{~m}$ in diameter. In the south, there is a small stone circle $(0.8 \mathrm{~m}$ diameter) located about $2 \mathrm{~m}$ north of the internal stone wall and a larger circle ( $2.1 \mathrm{~m}$ diameter) $12 \mathrm{~m}$ to its northwest. Test pits were placed inside stone circles in the north (Pit $\mathrm{C}$ ) and the south (Pit E; Figure 5.3). For comparative purposes, test pits were also excavated just outside of stone circles in the north and south (Pits A and D, respectively). An additional test pit (Pit B) was excavated within the southeastern area partially enclosed by a substantial stone wall. 

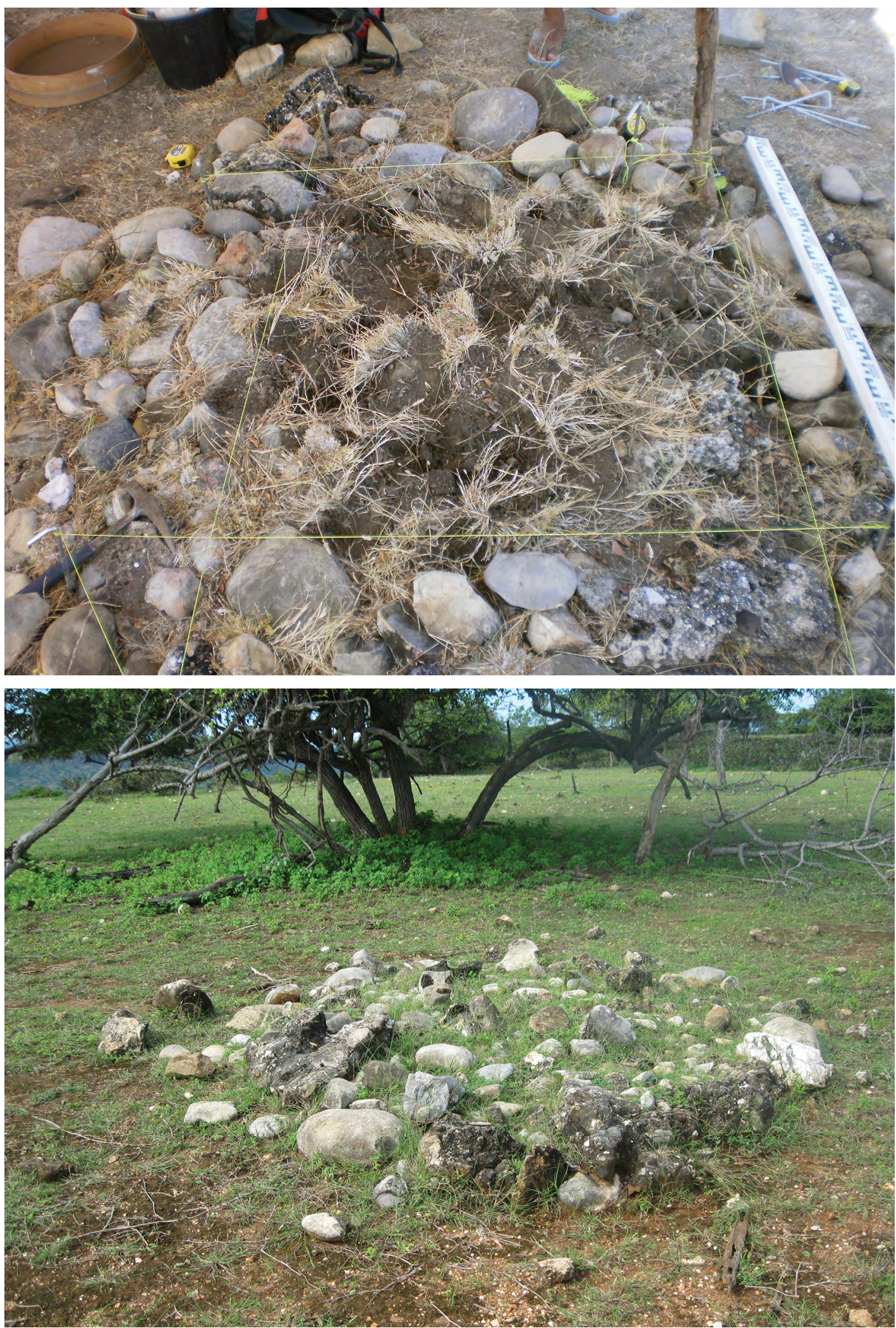

\section{Figure 5.3. Leki Wakik circular stone arrangements.}

Top: Stone circle in southern portion of the site showing Pit E position in 2011; Bottom: Large stone circle in northern portion of the site in 2010.

Source: Top photo courtesy of Jack Fenner, bottom photo courtesy of Sally Brockwell. 


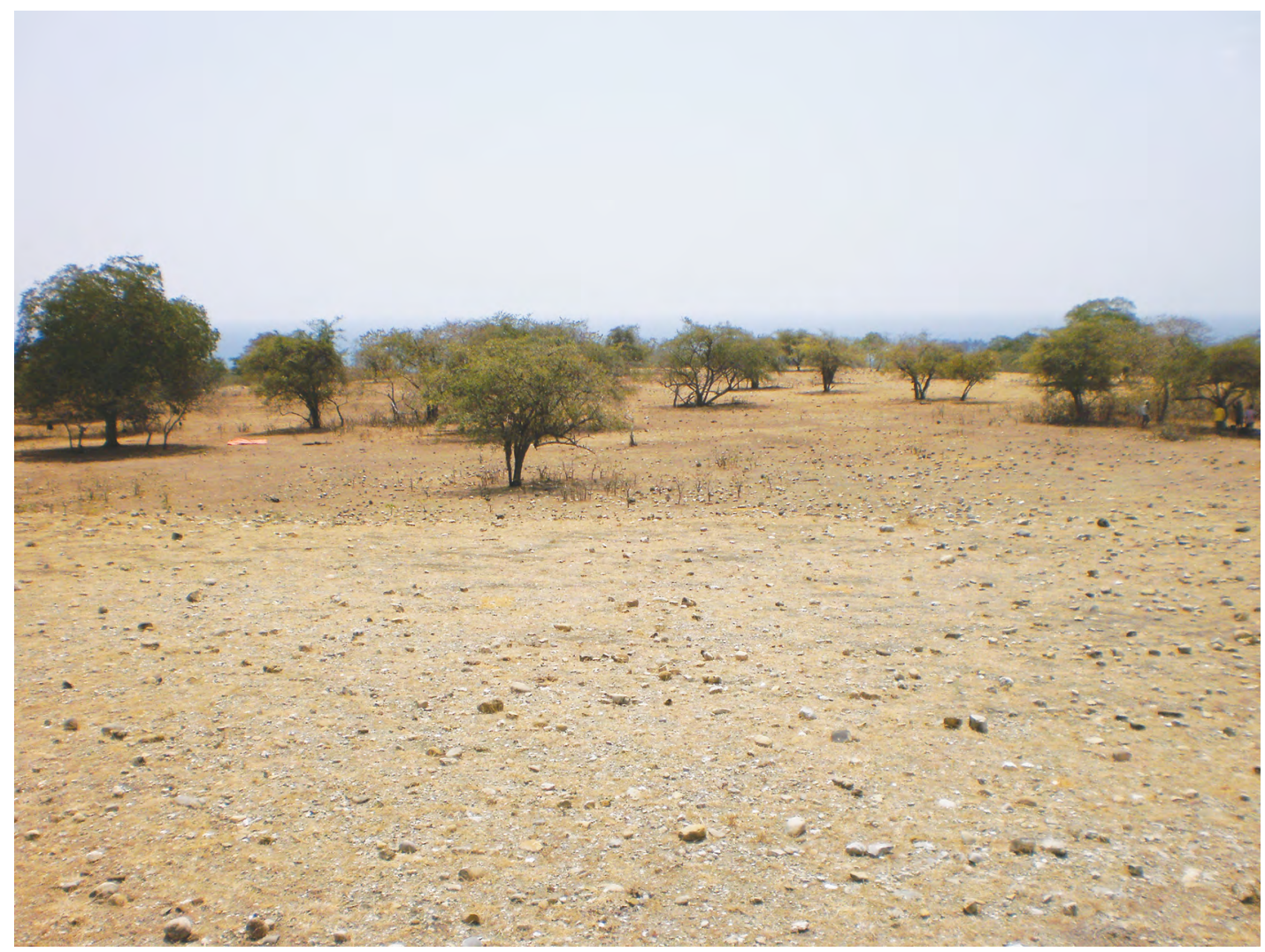

Figure 5.4. Typical view of Leki Wakik in August 2011.

The view is looking northeast from the vicinity of Test Pit E. Surface stones are present throughout the site and do not appear to be artefacts.

Source: Jack Fenner.

No clearly modern structures were present at the site. While the area is likely browsed regularly by goats (goats were twice herded across the site during the excavation period), there does not appear to have been cultivation or other large-scale recent anthropogenic or natural disturbance to the site. The present vegetation consists largely of grass clumps and occasional low trees. Trees are more abundant along the northern boundary of the site and on the hillslopes outside the site. Stones are abundant on the surface (Figure 5.4).

\section{Historical context}

Portuguese colonial archives offer no direct information about Leki Wakik, but the area lies within the former boundaries of the 'minor' kingdom (reino) of Laleia on the northern coast of Timor, and midway between the politically powerful indigenous domains of Manatuto and Vemasse that were early and prominent ports for maritime trade (McWilliam 2007). They share the common language of Galóli. During the late sixteenth and early seventeenth centuries, an intense rivalry developed between Portuguese, Dutch, Makassarese (from Sulawesi) and Chinese traders for access to the highly lucrative white sandalwood trade (Boxer 1948; Gunn 1999). Control over the supply and export of sandalwood by the Timorese coastal political domains bestowed upon them significant wealth and political autonomy. Trade in other desirable commodities also flourished, including the sale of war captives as slaves to work in the spice plantations of Banda and Batavia and commercial exchanges of guns and ammunition, textiles, beeswax, Chinese ceramics and other tradeware (McWilliam 2007). 
In the nineteenth century, the Regulo (ruler) of Laleia, along with the rulers of neighbouring Manatuto and Vemasse districts, formed an alliance with the Portuguese Colonial Government as military auxiliaries (arrarais) and reservists (moradores), and were active in the numerous bloody pacification campaigns against rebellious kingdoms in the interior of Timor (Davidson 1994). These campaigns were usually led by Portuguese military officers and featured mass looting and destruction of the opposition's defensive settlements accompanied by headhunting and the enslavement of women and children (Roque 2010). There is also evidence (Joliffe 1978:35) that late nineteenth- to early twentieth-century attempts by the Portuguese government to pacify the local people resulted in intense indigenous rebellion against the colonial regime (see also Pannell 2006:205).

According to contemporary residents of Laleia, a modern village about $3 \mathrm{~km}$ to the south, Leki Wakik is regarded as a 'sacred' (lulik) place-specifically an area containing a sacred marker, which was the focus of local offerings. It may have been a large black slab stone located on the northeastern arm of the site near the north side of the wall (Figure 5.5). It is a fine-grained sedimentary rock and has been worked into a circular or wheel shape with a longest dimension of $54 \mathrm{~cm}$, a width of $42 \mathrm{~cm}$ and a height of about $10 \mathrm{~cm}$. Similar stones have been found at Macapainara (see Chapter 2, this volume) and elsewhere in Timor-Leste (McWilliam et al. 2012). The name of the site, Leki Wakik, refers to an ancestral 'giant', and reflects the mythological traditions associated with it and nearby cultural heritage sites (for example, a nearby site is said to have a 'footprint' of the 'giant'). Leki Wakik may be the site of the old settlement and key historical stronghold for the Galôli-speaking settlers of the territory. We also recorded another former village site, Bai Hohon, located nearby, closer to the beach area, which had a number of graves. Local informants stated that Bai Hohon and Leki Wakik were of the same antiquity.

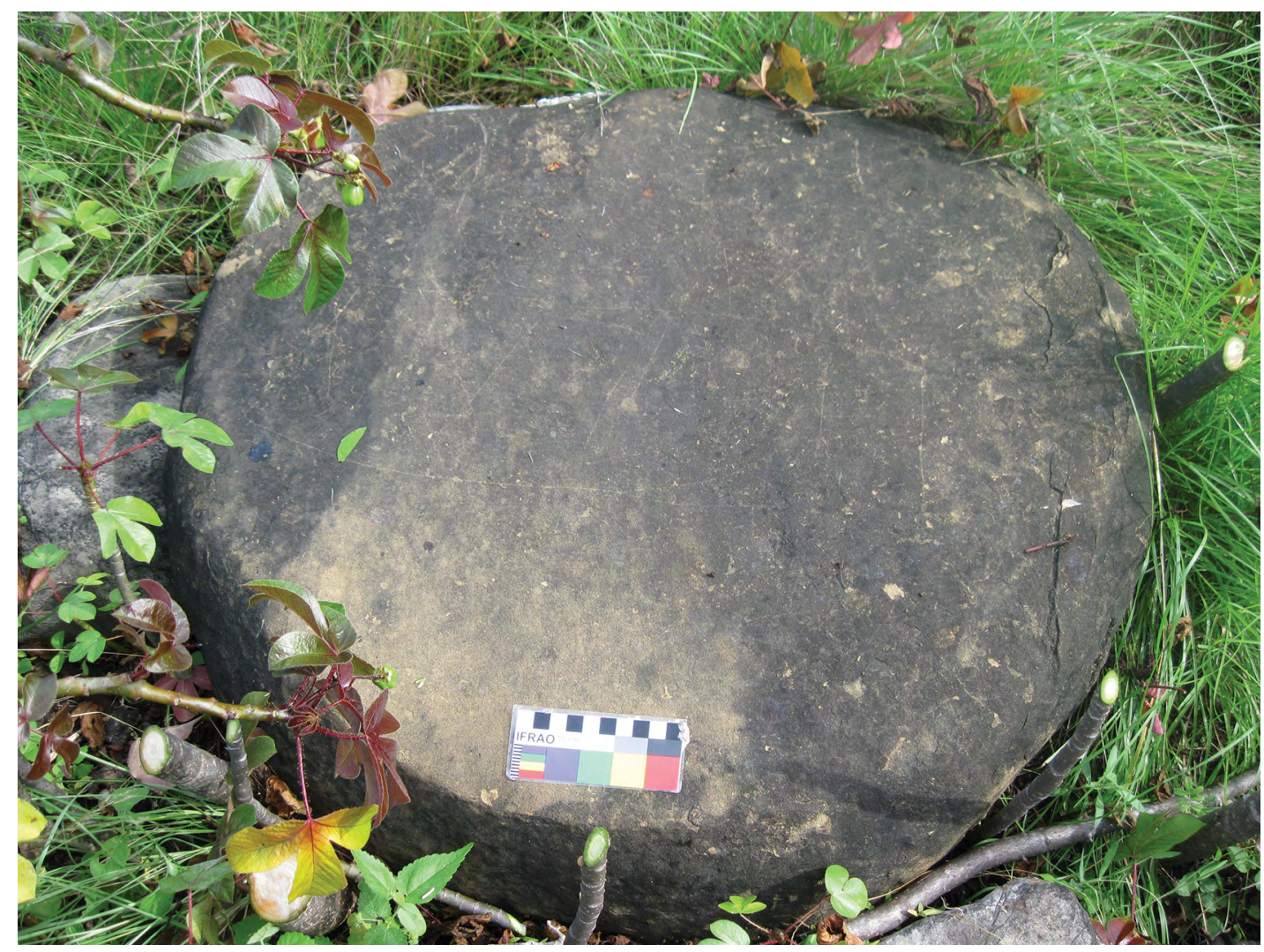

Figure 5.5. Leki Wakik large black slab stone considered sacred by Laleia villagers.

Source: Photo courtesy of Sally Brockwell. 


\section{Methods}

\section{Magnetometry}

Magnetometry was employed on 4 to 7 August 2011 across three grids to assist in selecting the locations for test pit excavations. It was performed using a Geometrics G-856AX proton precession magnetometer. The magnetometry grids were laid out using tape measures, with the corners subsequently mapped using a total station. Magnetic field intensity samples were taken at $1 \mathrm{~m}$ intervals. Transects were performed in a single direction and a single corner of the grid was sampled at the end of each transect to record fluctuations in background magnetism. Data were downloaded from the instrument and corrected for diurnal variation and other background magnetism fluctuations. While in the field, a basic magnetic field map was prepared using MagMap2000 software. Subsequent to fieldwork, the data were georeferenced using total station data and the maps shown in this report were created using ArcGIS 10.3.

\section{Excavation and mapping}

Five $1 \times 1 \mathrm{~m}$ test pits were excavated in arbitrary $5 \mathrm{~cm}$ spits. Sediment was separated from large rocks, and both the sediment and rocks weighed using a hand scale. Depths were measured using string levels from an arbitrary local datum point. In Pit B, significant artefacts and charcoal samples encountered while excavating were point-positioned. Due to time constraints, in the other pits only charcoal retained for dating purposes was point-positioned. Sediment was dry screened through $1.5 \mathrm{~mm}$ screens, and basic sorting was performed onsite. Sediment bulk samples were obtained from each spit, and the basal level of each spit was drawn and photographed. Sediment colours were recorded using Munsell soil colour charts, and $\mathrm{pH}$ estimated using simple barium sulphate $\mathrm{pH}$ dye kits. Excavation continued until culturally sterile sediment or bedrock was reached. A metal detector was used to scan below the final layer of each pit to check for remaining metallic artefacts; none were encountered (and only a single metallic artefact was found during excavations). At the end of excavation the stratigraphy of pit walls were drawn, then a plastic bag containing a short note giving basic excavation details was placed at the bottom of each pit and the pit refilled. Artefacts were washed and dried (to conform with Australian quarantine protocols) prior to packing and shipment to ANU.

Due to the intense sunlight at the site, plastic shades were erected over each test pit, resulting in a series of shallow, approximately $10 \mathrm{~cm}$ diameter modern postholes surrounding each pit. The site was mapped using a Leica TPS800 total station and GPR111 prism. Total station data were georeferenced using a basic Garmin GPS receiver.

\section{Lithics}

Stone artefact analysis involved an initial inspection and count of specimens, following the methods outlined in O'Connor et al. (Chapter 2, this volume).

\section{Earthenware pottery}

Earthenware weights were recorded for each square, and all sherds were examined from Square B, after Shepard (1974) and White and Henderson (2003). The following characteristics were recorded: sherd type (body/rim/base), paste (fine/medium/coarse), weight (to the nearest tenth of a gram), thickness ( $\mathrm{mm}$ ), length (maximum dimension in $\mathrm{mm}$ ), width $(\mathrm{mm})$, forming technique (if it could be discerned), angle, articulation and stance of the rim, exterior surface treatment and evidence for surface treatment, surface lustre (plain, dull, bright), exterior surface Munsell colour, whether the surface was oxidised or reduced, exterior decoration type and variety, 
exterior use-wear or damage (sooting, abrasion, pitting, spalling, scratching etc.), interior surface treatment and evidence for treatment, interior surface lustre (plain, dull, bright), interior surface forming evidence, interior surface Munsell colour, whether the interior surface was oxidised or reduced, evidence for interior use-wear and whether the core was oxidised or reduced.

\section{Tradeware ceramics}

High-fired glazed ceramics at Leki Wakik are classified as tradeware ceramics and were analysed using a macroscopic (visual) comparative analysis. A Canon EF $100 \mathrm{~mm}$ f/2.8 Macro USM lens was used to take photo-macrographs (up to 1:1 magnification) of both exterior and interior surfaces as well as fabric cross-sections of the sherds. These photo-macrographs allowed for a finer resolution of diagnostic details that are otherwise difficult to observe and record with the naked eye. Forty-seven metric and non-metric variables were recorded. Non-metric data (i.e. provenance, vitrification level, fabric texture, fabric, glaze colours and others) were assessed based on the analyst's (Tse Siang Lim) knowledge and familiarity with high-fired glazed ceramics produced in China and Mainland Southeast Asia. This data should be treated as preliminary and, hence, should not be used in comparisons with other high-fired glazed ceramics outside of the Leki Wakik assemblage without caution.

As per standard taxonomical practice in the analysis of high-fired glazed ceramics, the Leki Wakik sherds have been preliminarily classified according to typologies based on their respective glaze and body colours and, in the case of Polychrome and Blue and White sherds, glaze colourdecoration combination. Additional information on tradeware ceramic analysis methods is provided in Supplement 1.

\section{Invertebrate faunal remains}

Marine and freshwater shells and shell fragments were identified to the lowest taxonomic level possible using the ANU Archaeology and Natural History (ANH) and the Museum and Art Gallery of the Northern Territory malacology collections. The names were standardised to conform with the current listing on the online database, the World Register for Marine Species. The shell assemblages were quantified by weight ( $\mathrm{g}$ ), minimum number of individuals (MNI) and number of identified specimens (NISP). The MNI method quantifies one repetitive feature per taxon throughout the assemblage, thereby avoiding the inflation associated with fragmentation commonly seen when using NISP counts (Classen 1998); for this reason, it is the primary mode of quantification used in the analysis.

The MNI was calculated through the use of the same non-repetitive element for each taxon, which included the aperture for the two Stenomelania species, the spires for all other gastropods, the posterior valve for chitons, and the siphon for Nautilus species. Both the left and right hinges were counted for bivalves with the greater number selected per square. Turbo sp. was quantified during laboratory analysis; however, opercula counts are excluded from aggregative family calculations to avoid inflating Turbinidae quantities. Shell and shell fragment condition and evidence for cultural modification were noted during quantification.

\section{Vertebrate faunal remains}

Vertebrate skeletal elements were identified to the lowest taxonomic level possible by comparison with reference material held at the ANU ANH Osteology reference collection. Large bovids were further distinguished based on size and morphological comparison of teeth using photographic references provided by Phil Piper. Bones were quantified using NISP and weight (g) to 
compensate partially for biases of fragmentation; MNI was not assessed using bones due to issues of interdependence and assemblage aggregation of large fauna and its overemphasis of rare species (Lyman 2008).

Taphonomic indicators of pre- and post-depositional processes were assessed to distinguish cultural butchery practices from natural post-mortem bone surface modifications. Green fracture patterns were assessed based on fracture shape using a schematic designed by Sadek-Kooros (1975) whereby obtuse, helical (spiral), and acute fracture angles with smooth fracture surfaces are considered fresh fractures (often the result of butchery) while irregular fracture shapes with rough surfaces are considered post-depositional breaks (Coil et al. 2017). The data were crosschecked by observing bone surface marks such as tooth, percussion, and trampling marks to confirm the agent of bone breakage (e.g. Galán et al. 2009). Weathering and root etching were also observed based on morphologies described by Behrensmeyer (1978), but only the presence or absence of severe degradation (more than stage 3 ) was recorded. Burning was estimated based on a colour scale of $0-5$ (Stiner et al. 1995), whereby blackened carbonised bone is 3 and calcined bones are 4-5. This was crosschecked for other bone-burning morphologies such as shrinkage and surface structure (Shipman et al. 1984).

\section{Results}

\section{Magnetometry}

Two magnetometry grids were positioned within the northern and southern stone circle areas, while the third was placed such that it spanned the partially fenced-in area in the southeast of the site (Figure 5.6). The resulting magnetic field maps show several commonalities.

First, all three show linear patterns aligned with one of the grid axes. These patterns correspond closely to the linear sampling transects and are very likely to be sampling artefacts, perhaps related to a changing background magnetic field. While diurnal variation was accounted for by sampling a single location at the start of each transect and subsequently applying an appropriate correction factor, minor fluctuations that occur during each transect itself cannot be accounted for with this method. Likewise, instrument variation or alignment differences amongst transects could produce anomalous linear features. Second, the range of magnetic field variation is low in all grids. For instance, the range of magnetic field variation across all of Grid 1 (after adjusting for diurnal variation) was 10.0 nanoTeslas; the Grid 1 diurnal variation itself was over 25 nanoTeslas. This provides further indication that much of the magnetic variation was due to fluctuations in the noise rather than signals of archaeological relevance. Finally, the grids do not show clear magnetic anomalies in areas with above-ground stone circles (Grids 1 and 2) or stone walls (Grid 3). This suggests that these stone features are not magnetically active and that magnetometry likely would not reveal the presence of similar features buried below the surface. There are a few areas within the grids that display interesting or suggestive patterns, such as the green area in the west of Grid 2, which seems to bend and interrupt a red area. However, no sharp, clearly anthropogenic patterns are displayed, and whether the patterns in these suggestive areas are truly significant cannot be determined without extensive excavation. Therefore, the magnetometry data were disregarded, and the positioning of excavation pits based on other factors, such as assessment of the function of the stone circles and the unusual walled-in area in the southeast of the site. 


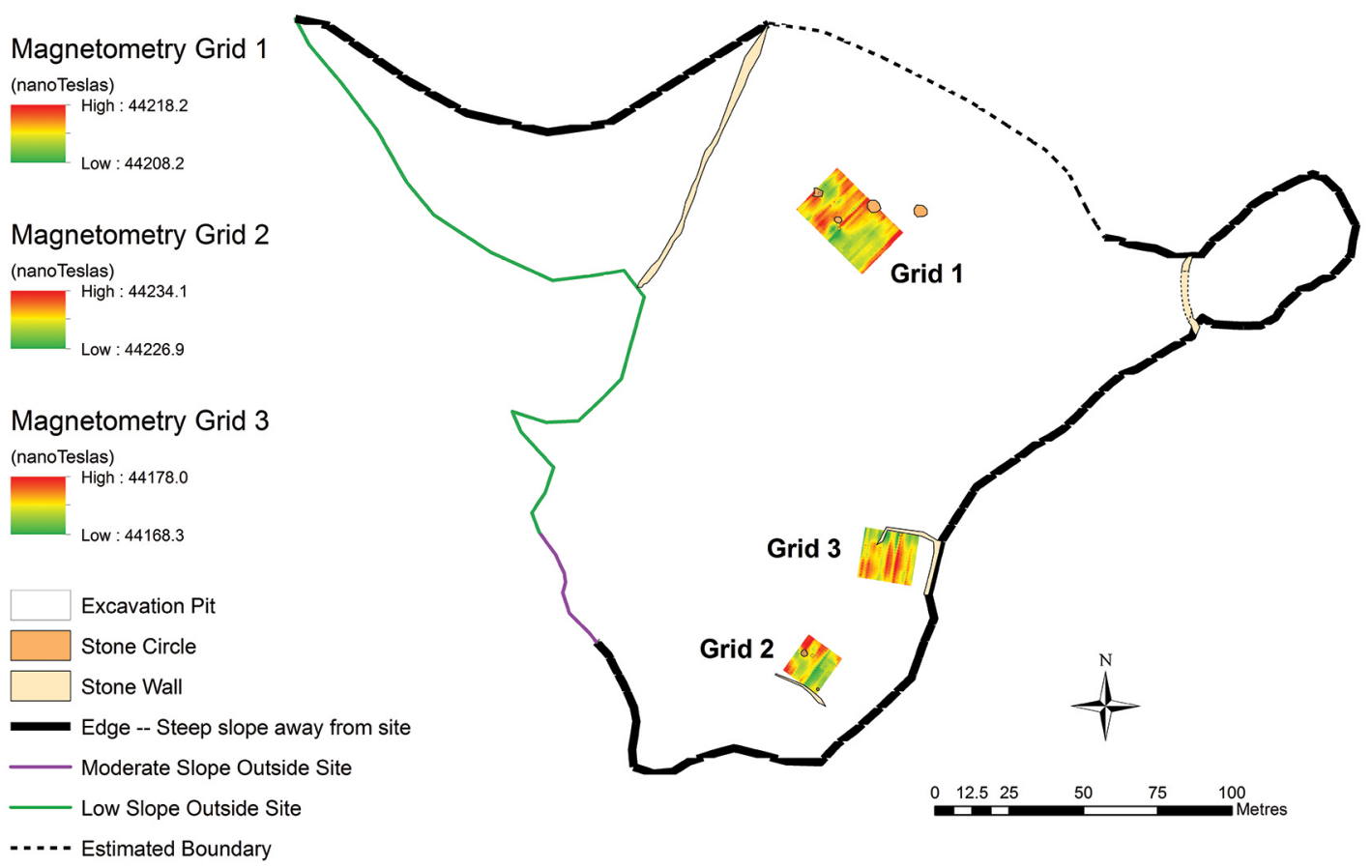

Figure 5.6. Leki Wakik magnetometry grid locations.

Source: Jack Fenner.

\section{Excavation and survey}

Appendix Table 5.A1 shows the weights of sediment, stone and each artefact type recovered during excavations; Supplement 2 contains more detailed artefact data. We will briefly review the stratigraphy and other relevant aspects of each excavation pit in this section, and then present the results of more detailed artefact analyses in subsequent sections.

\section{Test Pit A}

Test Pit A was located in the northern portion of the site (Figure 5.2), and was about $12 \mathrm{~m}$ southeast of Test Pit C (Figure 5.7). It was about $1.4 \mathrm{~m}$ south of a stone circle, in an area with thin vegetation-mostly dry grass - and highly compacted surface sediment. Eight spits were excavated and two stratigraphic units (SU) were revealed. SU 1 is a grey brown, fine sandy silt, which is poorly sorted. SU 2 is a red brown, fine sandy silt, and is poorly sorted, with angular gravel and cobbles (Figure 5.8). Mollusc shell was found in all SUs, and in all spits except Spit 8, while earthenware was located in Spits 2 to 5 and 7. Tradeware ceramics were limited to the uppermost spits and SU 1. A small amount of concrete was found in Spit 2, and bone and coral were largely confined to the upper four spits.

The stratigraphy shows several intrusions by SU 1 into SU 2 (Figure 5.8); these may be postholes and/or animal burrows. Stratigraphic disturbance is also supported by accelerator mass spectrometer (AMS) radiocarbon analysis of a charcoal sample from Spit A7 (the lowest cultural layer in Test Pit A), which produced a modern date (Appendix Table 5.A2). Unfortunately, the sample was not piece-plotted and it is unknown whether it derived from one of the deep intrusions by $S U 1$. 

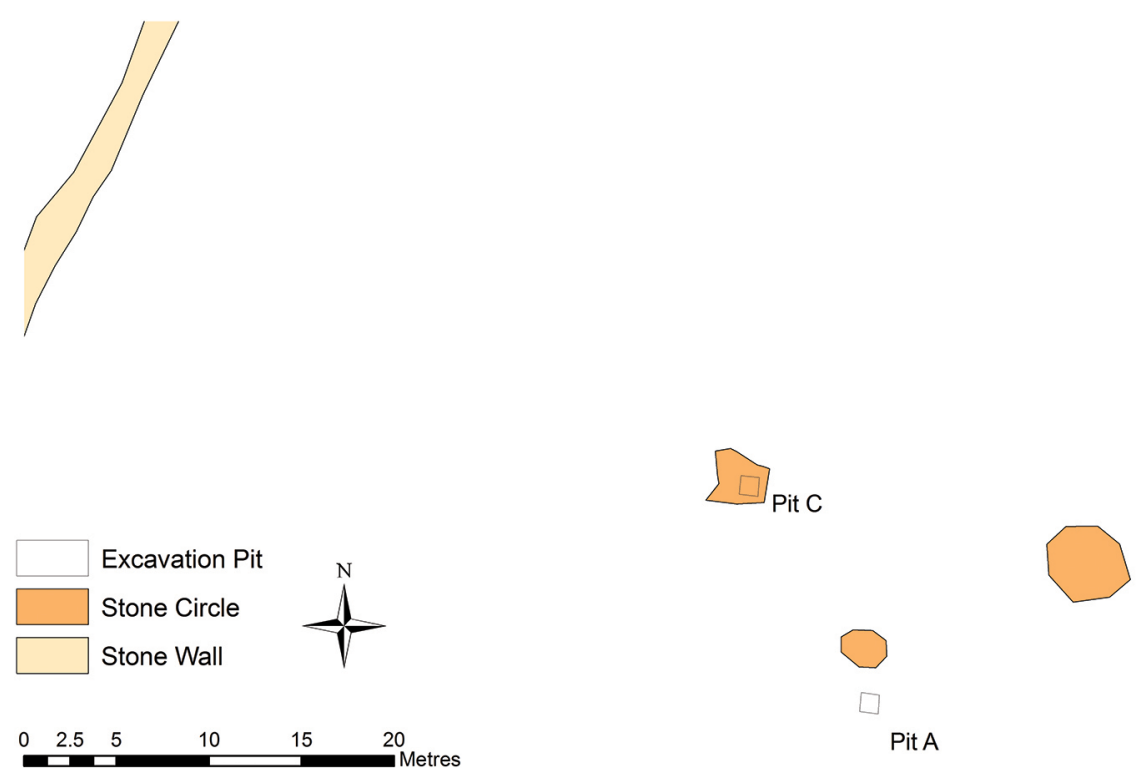

Figure 5.7. Leki Wakik Test Pits $A$ and $C$ in the northern area of site.

Source: Jack Fenner.

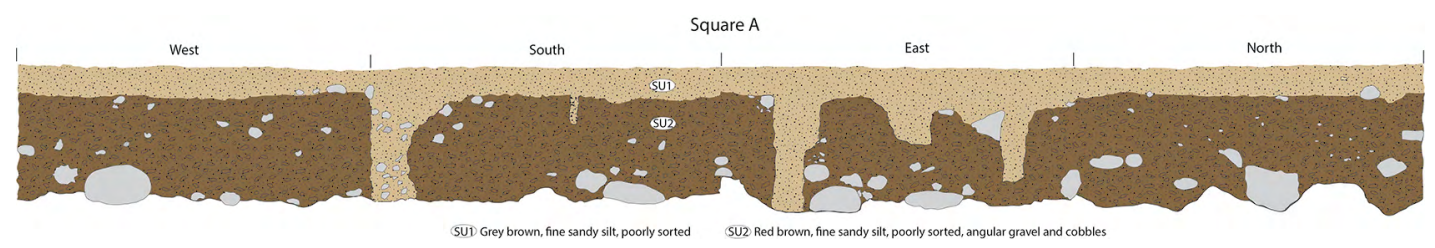

Figure 5.8. Leki Wakik Test Pit A section drawing.

Source: Tim Maloney.

\section{Test Pit B}

Test Pit B was located near the eastern edge of the site boundary (Figure 5.2), adjacent to a stone wall (Figure 5.9). The surface contained sparse grass and several large stones. The excavation revealed five SUs within 14 spits. This represents substantially more artefact-bearing sediment accumulation than is present in other Leki Wakik test pits, probably due to build-up along the adjacent stone wall. SU 1 is a fine, well-sorted brown silt of moderate compaction (Figure 5.10). It contained abundant animal bone and earthenware pottery, as well as marine, freshwater and terrestrial mollusc shell and small amounts of tradeware ceramics (Table 5.A1). Active bioturbation was observed in the southeastern corner.

The second SU is a fine brown silt, well sorted, with loose to moderate compaction. This extended generally from about $10 \mathrm{~cm}$ in depth to $40-50 \mathrm{~cm}$. This layer included the majority of the cultural materials, including mollusc shell, bone, lithics and ceramics.

The third SU is composed of poorly sorted silt and gravel, and had loose to moderate compaction. Most classes of cultural material were found in this layer, except for terrestrial gastropod shell, which stops at SU 2. SU 4 refers to a small lens of pale brown fine silt with gravel, which is well sorted, and well compacted (Figure 5.10). SU 5 is a gravel with silt, which is poorly sorted and of moderate compaction. This SU contained marine and freshwater shell, crustacean, charcoal, earthenware pottery and a very small number of lithics in Spits 10 and 11. No cultural material was found in Spit 13. 


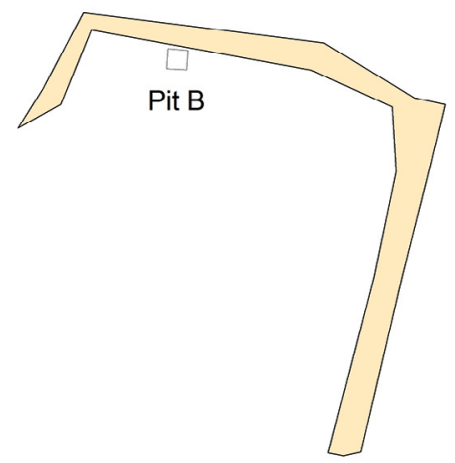

Pit E

Pit D

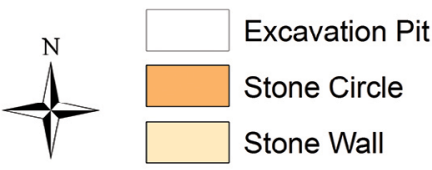

2.755 .5

11

16.5

Metres

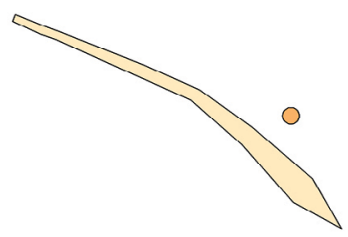

Figure 5.9. Leki Wakik southeastern excavation area.

Source: Jack Fenner.

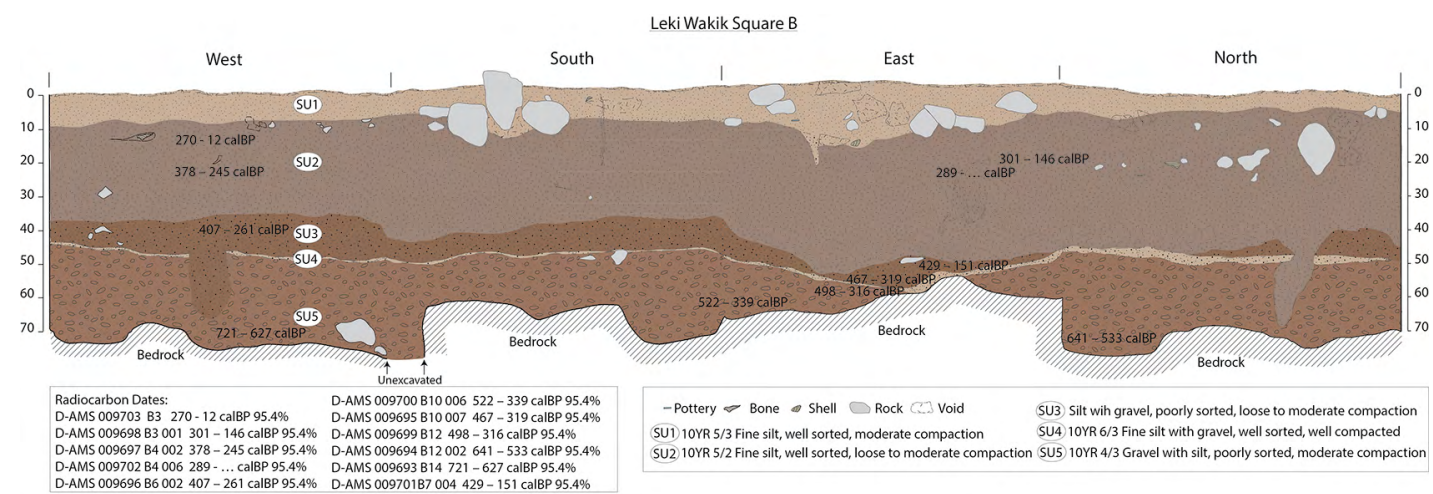

Figure 5.10. Leki Wakik Test Pit B profile drawing.

Source: Tim Maloney.

Eleven AMS radiocarbon dates were obtained for Test Pit B (Table 5.A2; Figure 5.11). Six of the dates were obtained from various marine shells with the remainder from charcoal, which has not been identified to species. Unfortunately, the marine shell $\Delta \mathrm{R}$ calibration offset is unknown for Timor-Leste, so the shell dates have large uncertainties and are not further discussed here. The charcoal dates are in stratigraphic order and indicate that SU 2 dates to the seventeenth to nineteenth centuries $\mathrm{AD}$, while $\mathrm{SU} 4$ dates to the late fifteenth to mid-seventeenth centuries $\mathrm{AD}$ (Figure 5.11). 


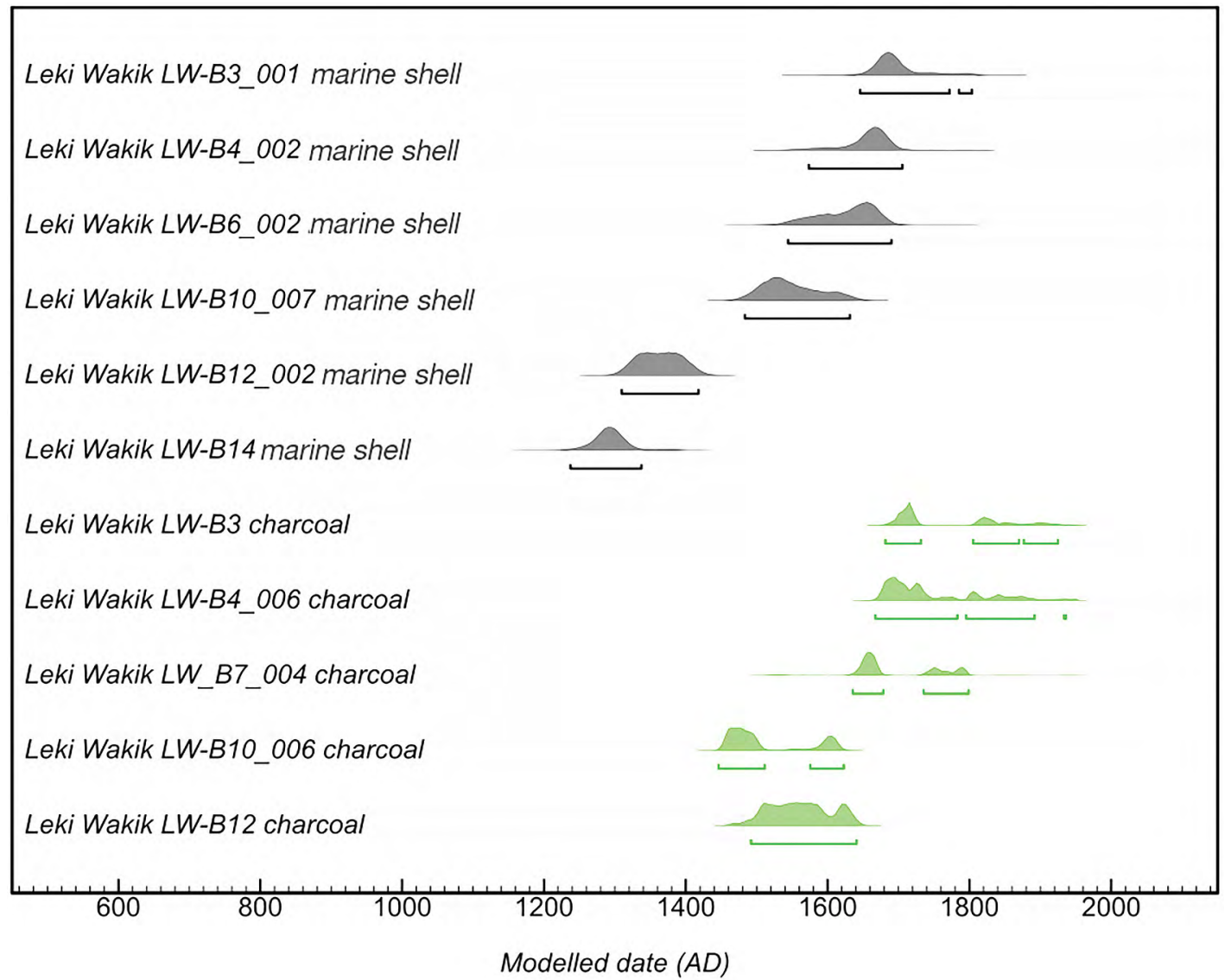

Figure 5.11. Leki Wakik Test Pit B calibrated marine shell and charcoal radiocarbon dates.

Source: Jack Fenner. See Table 5.A2 for calibration information.

\section{Test Pit $C$}

Test Pit $C$ was located in the northern portion of the site (Figure 5.2) and was about 12 m northwest of Test Pit A (Figure 5.7). It was placed inside a 2.0 to $2.4 \mathrm{~m}$ diameter stone circle, and contained shell, coral, charcoal, artefactual stone, earthenware pottery, tradeware ceramics and metal (Table 5.A1). Two SUs and seven spits were excavated with metal found in the uppermost SU along with coral of an unknown type. All other cultural materials were found throughout both SUs. SU 1 is a fine, poorly sorted sandy silt while SU 2 is similar but darker in colour (Figure 5.12).

An attempt to date charcoal from Spit 1 was unsuccessful, as the sample did not survive the lab's pre-treatment processes. It may, in fact, have been a black mineral-enriched clay rather than charcoal.

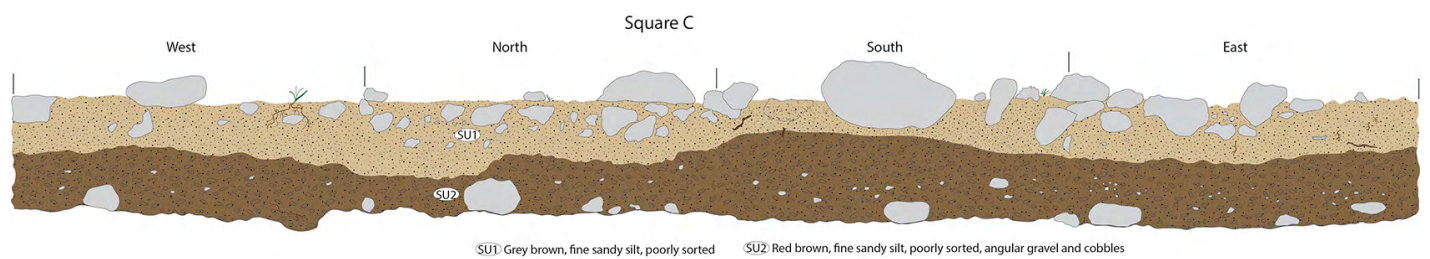

Figure 5.12. Leki Wakik Test Pit C section drawing.

Source: Tim Maloney. 
Test Pit D

Test Pit D was located in the southern portion of the site (Figure 5.2), and was about $1.5 \mathrm{~m}$ southeast of Test Pit E (Figure 5.9). The surface was covered with light grey silty sand with patches of dry grass, and slopes gently down towards the south. Test Pit D contained marine and freshwater shell, terrestrial gastropod shell, crustacean, urchin, coral, charcoal, artefactual stone, earthenware and tradeware (Table 5.A1). No radiocarbon dating has been attempted for Test Pit D.

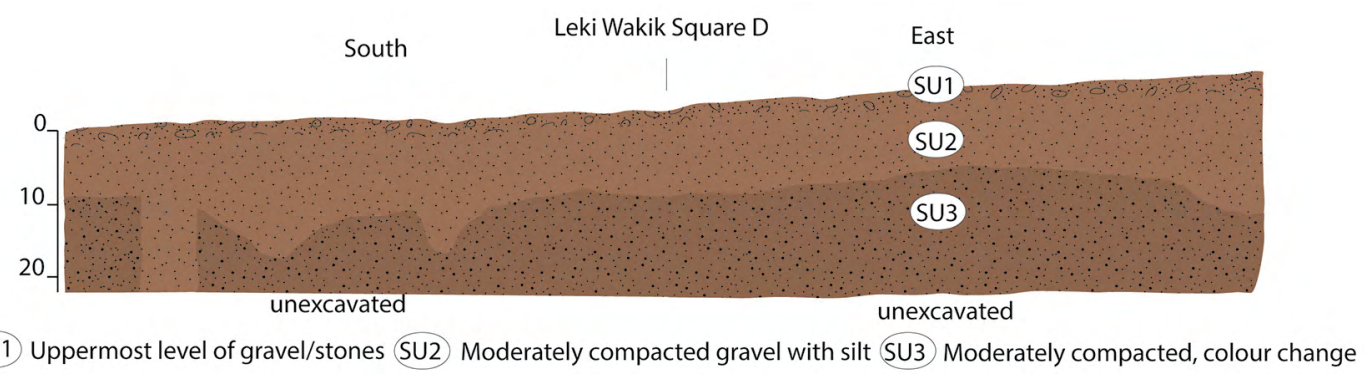

Figure 5.13. Leki Wakik Test Pit D section drawing.

Source: Tim Maloney.

Due to time constraints, profiles were only drawn for the south and east walls (Figure 5.13). Three SUs were noted, including a thin uppermost layer of gravel and larger stones. Five spits were excavated until culturally sterile sediment was reached. Marine, terrestrial and freshwater shell was found in all units and spits. Stone and earthenware were also found throughout the excavation. Tradeware was only recovered from Spit 2.

\section{Test Pit E}

Test Pit E was located in the southern portion of the site (Figure 5.2), and was about $1.5 \mathrm{~m}$ northwest of Test Pit D (Figure 5.9). It was placed inside a $2.1 \mathrm{~m}$ diameter stone circle. It contained marine and freshwater shell, terrestrial gastropod shell, crustacean, coral, seeds, charcoal, artefactual stone, earthenware and tradeware (Table 5.A1). No cultural material was found in its top spit, which consisted entirely of rocks and was slightly above the surrounding ground surface. No radiocarbon dating has been attempted for Test Pit E.

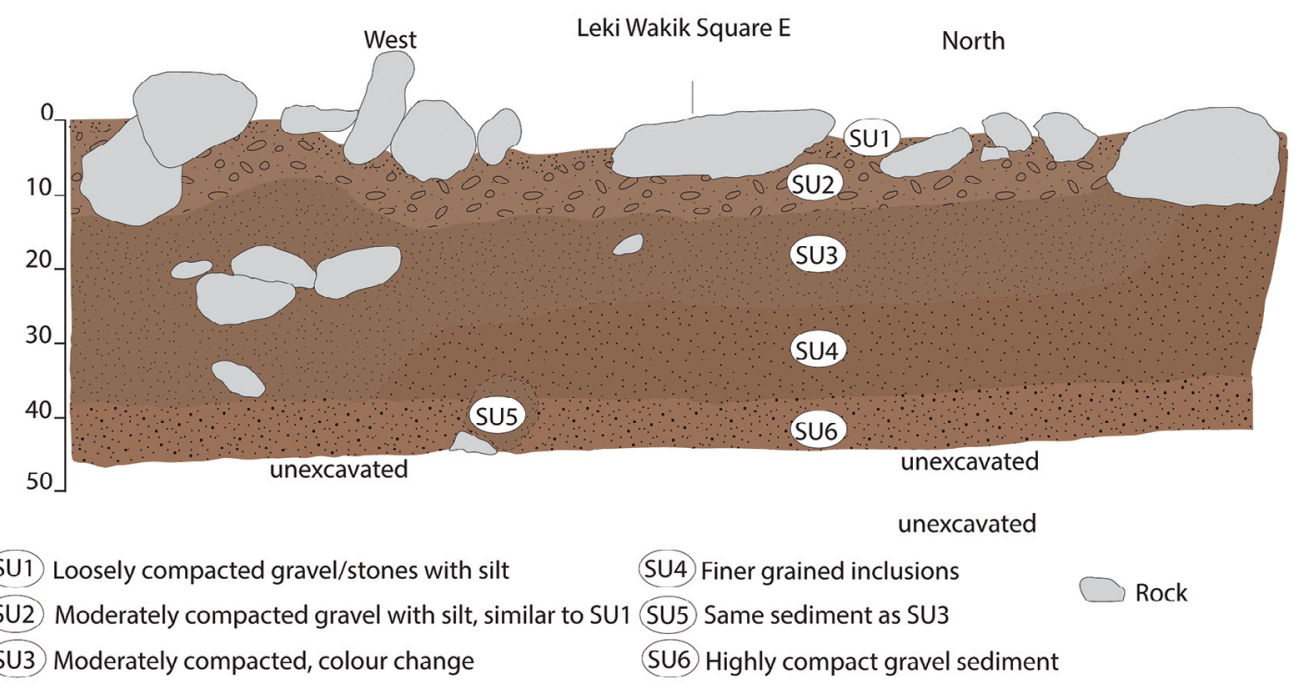

Figure 5.14. Leki Wakik Test Pit E section drawing.

Source: Tim Maloney. 
Due to time constraints, profiles were only drawn for the west and north walls of Test Pit E (Figure 5.14). The majority of cultural material was found in Spits 4 (44 per cent) and 5 (30 per cent). Earthenware, terrestrial gastropod and shell were present in all spits, apart from Spit 1, with stone, seed and charcoal found in most. The greatest artefact weight was associated with marine and freshwater shell, followed by earthenware. Terrestrial gastropods were most numerous in Spits 1-5, with lower weights in Spits 6-7. Crustacean, coral, artefactual stone and tradeware were all found in minimal quantities in Spits 4-6.

\section{Artefact analyses}

All artefacts recovered during excavation were sorted by primary classification type and analysed as described in the Methods section. The results of these analyses for each artefact type are provided in the following subsections, with a subsequent section considering artefact patterns across classification types.

\section{Lithics}

A total of 32 stone artefacts were recovered across the excavation squares, consisting of flakes and flake fragments made either of chert or other fine grain sedimentary stone (Figure 5.15, Table 5.A1). These flakes are anomalous in their geological context so are undoubtedly artefacts, but it is unclear what they were used for. No lithic artefacts exhibited signs of use and cannot be described as strike-a-lights, in contrast to lithics from Macapainara and Vasino (see Chapters 2 and 4 in this volume).
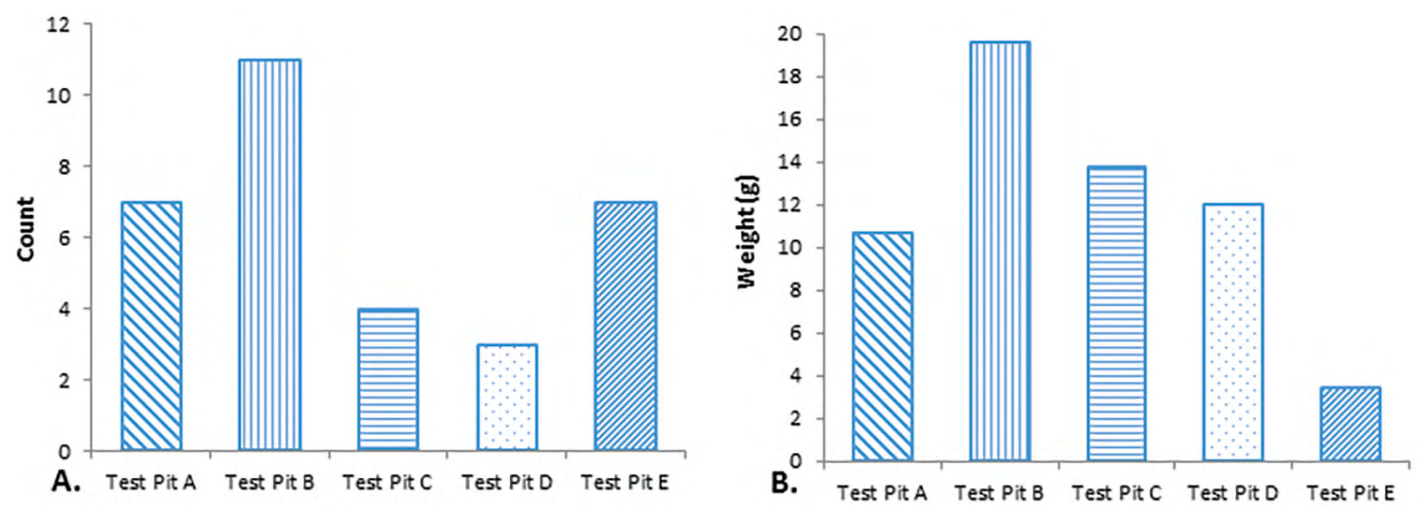

Figure 5.15. Leki Wakik lithics counts (A) and weights (B) by test pit. Source: Jack Fenner.

\section{Earthenware pottery}

Earthenware was the second most abundant material (by weight) returned from excavations at Leki Wakik, with $4.7 \mathrm{~kg}$ recovered. Test Pit $\mathrm{C}$ contained the most, weighing $2045.1 \mathrm{~g}$, while Test Pit A had the least, weighing $186.8 \mathrm{~g}$. Despite extending considerably deeper than the other pits, Test Pit B contained a similar earthenware sherd weight $(815.9 \mathrm{~g})$ as Test Pits D $(877.5 \mathrm{~g})$ and E (732.7 g) (Table 5.A1). 
As noted previously, detailed analysis was performed on earthenware sherds from Test Pit B. Results of this analysis are presented in Supplement 2 and summarised here. The majority were undecorated body sherds with only nine ( 2.2 per cent) classified as rim sherds, and two ( 0.5 per cent) as shoulders. Nine sherds were decorated with reddish claybased paint or a black paint used to create abstract decorations (e.g. Figure 5.16). These are comparable to those also present in small quantities at Macapainara (Chapter 2, this volume) and Vasino (Chapter 4, this volume). The remaining decorated sherds were paddleimpressed with lines.

Slips were recorded on 49 sherds (12 per cent of all sherds). They were applied more often to external surfaces than internal surfaces with only six sherds recorded with internal slippage. Red slips dominated $(\mathrm{N}=32)$, with other slips including black slip $(\mathrm{N}=8)$, brown slip $(\mathrm{N}=6)$ and small amounts of white slip $(\mathrm{N}=2)$. White slipping likely involved the application of calcareous-rich clay. External colour was recorded on all sherds and classified by Munsell colour groups. The most common colours are grey $(\mathrm{N}=114,28$ per cent $)$ and brown $(\mathrm{N}=98,24$ per cent). Red was recorded on 73 sherds (18 per cent), while 68 were black (17 per cent), 36 were reddish brown ( 9 per cent), 18 were pink ( 4 per cent), four were recorded as reddish yellow and one as white (Table 5.1).

Wiping marks were apparent on one sherd. Burnishing was also apparent on one black sherd, perhaps through the use of a pebble. Four completely reduced sherds contained carbonised residues on the internal surface, indicating likely cooking at the site. Constituting 99.5 per cent of the site assemblage, 410 sherds showed evidence of dark or grey cores, pointing to reduced firing conditions. Vessels were likely mostly formed through an external application of a paddle against an anvil held against the interior wall. Sometimes paddle impressions can be discerned.
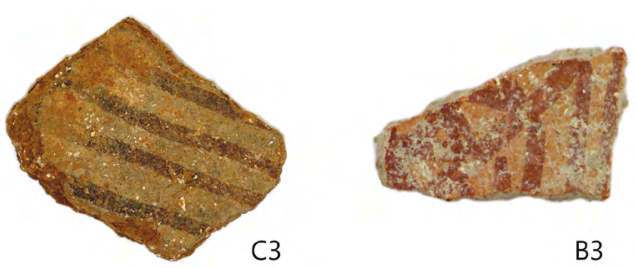

B3
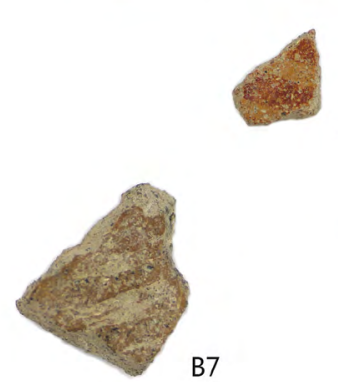

B7

B7

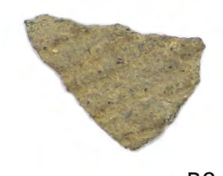

B8

Figure 5.16. Leki Wakik examples of decorated sherds.

The top three have an iron oxide abstract design (paint applied). The bottom two have paddle-impressed lines. The label is the spit in which the sherd was found.

Source: Mirani Litster.

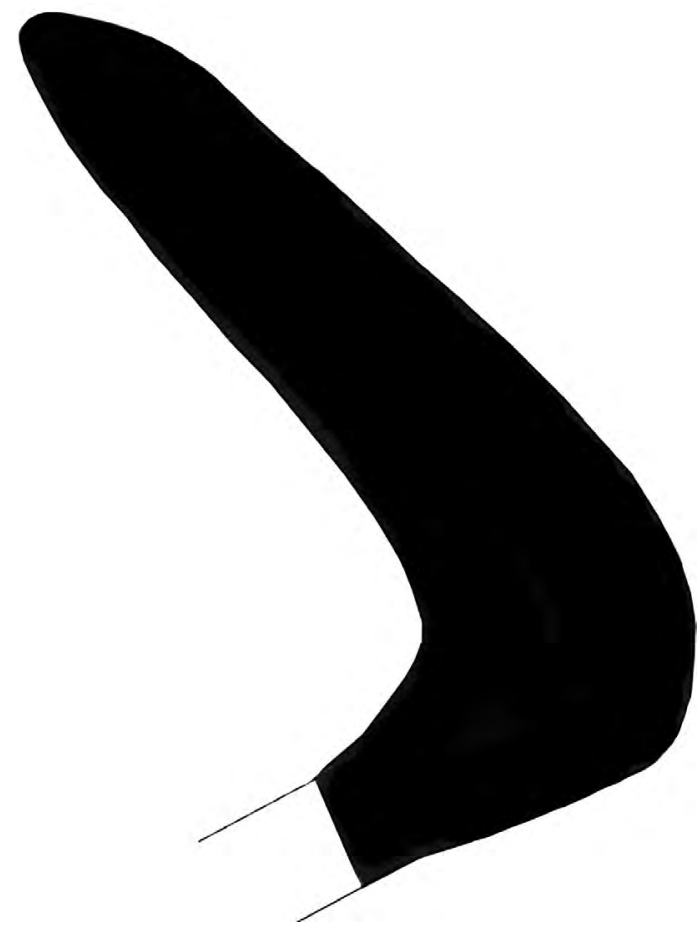

Figure 5.17. Leki Wakik rim type 1.

Source: Mirani Litster. 
Table 5.1. Leki Wakik Test Pit B earthenware sherd external surface colour by spit.

\begin{tabular}{|l|c|c|c|c|c|c|c|c|c|c|}
\hline & Grey & Black & Red & Reddish brown & Brown & Reddish yellow & Pink & White & Total \\
\hline Test Pit B & 4 & - & 1 & - & - & - & - & 1 & 6 \\
\hline 1 & 16 & - & - & 18 & - & - & - & - & 34 \\
\hline 2 & 14 & 18 & 10 & 12 & 10 & 4 & 1 & - & 69 \\
\hline 3 & 2 & 13 & 8 & 6 & 4 & - & 6 & - & 39 \\
\hline 4 & 20 & 4 & 1 & - & 14 & - & 3 & - & 42 \\
\hline 5 & - & 1 & 5 & - & 3 & - & - & - & 9 \\
\hline 6 & 11 & - & 12 & - & 8 & - & 3 & - & 34 \\
\hline 7 & 10 & 14 & 10 & - & 23 & - & 3 & - & 60 \\
\hline 8 & 25 & 6 & 16 & - & 19 & - & 2 & - & 68 \\
\hline 9 & 7 & 4 & 9 & - & 12 & - & - & - & 32 \\
\hline 10 & 2 & - & 1 & - & - & - & - & - & 3 \\
\hline 11 & 3 & 7 & - & - & 5 & - & - & - & 15 \\
\hline 12 & - & - & - & - & - & - & - & - & 0 \\
\hline 13 & - & 1 & - & - & - & - & - & - & 1 \\
\hline 14 & 114 & 68 & 73 & 36 & 98 & 4 & 18 & 1 & 412 \\
\hline Total & & & & & & &
\end{tabular}

Source: Authors' summary.

The entire assemblage was fragmentary and ceramic form could not be discerned (unlike at Macapainara and Vasino). Test Pit B sherds were small, with an average thickness of $4.5 \mathrm{~mm}$ taken at a central point of the sherd. Nine rim sherds were identified, and one discernible rim sherd type can be seen (Figure 5.17). It is a long rounded, brown rim with an everted lip. Examples were found in Spits B2, B4, B7 and B12. No discernible differences associated with colour, surface treatment or decoration could be seen between SUs.

No wasters are recorded in the Test Pit B assemblage (or observed in the whole ceramics assemblage from Leki Wakik), indicating pottery manufacture likely did not occur at this location.

\section{Tradeware ceramics}

The high-fired glazed ceramics assemblage at Leki Wakik includes 44 sherds weighing a total of 276.4 g. Six sherds were recovered from Test Pit A, 15 from Test Pit B, 21 from Test Pit C and one each from Test Pits D and E (Table 5.2; dashes in the table indicate zero sherds). Thirty-six have been classified as Chinese, with the remaining sherds also consistent with Chinese origin. Eleven are attributed to the Ming Dynasty (1386-1644), with a further 13 also likely associated with same dynasty. Dating for the other sherds is uncertain or very broad. The colour of the glaze and the type of decoration suggests that a white sherd in Test Pit A Spit 1 is likely to be a Chinese ceramic from the Dehua (德化 Dé Huà) kiln complex in Fujian Province. Detailed discussion of the ceramic assignments and other tradeware results is provided in Supplement 1. 
Table 5.2. Leki Wakik tradeware sherd typology distribution.

\begin{tabular}{|l|c|c|c|c|c|c|c|c|c|c|c|}
\hline Test Pit & Spit & Brown & Green & White & $\begin{array}{c}\text { Qing } \\
\text { Bai }\end{array}$ & $\begin{array}{c}\text { Blue and } \\
\text { White }\end{array}$ & Polychrome & $\begin{array}{c}\text { Brown and } \\
\text { white }\end{array}$ & $\begin{array}{c}\text { light and } \\
\text { dark green }\end{array}$ & Undiagnostic & $\begin{array}{c}\text { Spit } \\
\text { total }\end{array}$ \\
\hline A & 1 & - & - & 1 & - & 1 & 2 & - & - & - & 4 \\
\hline A & 2 & - & - & - & - & - & 2 & - & - & - & 2 \\
\hline B & 2 & - & - & - & - & $1 ?$ & $1 ?$ & - & - & 1 & 1 \\
\hline B & 3 & - & - & - & - & $1 ?$ & $1 ?$ & - & - & 1 & 1 \\
\hline B & 4 & 1 & - & - & - & $1 ?$ & $1 ?$ & - & - & 1 & 2 \\
\hline B & 6 & - & - & - & - & - & 1 & - & - & - & 1 \\
\hline B & 7 & 1 & 1 & - & - & 1 & - & - & - & - & 3 \\
\hline B & 8 & - & - & - & - & 2 & - & - & - & - & 2 \\
\hline B & 9 & 1 & - & - & - & - & - & - & - & - & 1 \\
\hline B & 10 & - & - & - & - & 2 & - & - & - & - & 2 \\
\hline B & 11 & - & - & - & - & 2 & - & - & - & - & 2 \\
\hline C & 1 & - & 1 & 1 & - & 1 & - & 1 & - & - & 4 \\
\hline C & 2 & - & - & - & - & $3(+2 ?)$ & $1(+2 ?)$ & - & 1 & 2 & 7 \\
\hline C & 3 & - & - & - & - & 5 & 2 & - & - & - & 7 \\
\hline C & 4 & - & - & - & - & $1 ?$ & $1(+1 ?)$ & - & - & 1 & 2 \\
\hline C & 5 & - & - & - & - & $1 ?$ & $1 ?$ & - & - & 1 & 1 \\
\hline D & 2 & - & 1 & - & - & - & - & - & - & - & 1 \\
\hline E & 4 & - & - & - & $1 ?$ & - & - & - & - & 1 & 1 \\
\hline Total & & 3 & 3 & 2 & 0 to 1 & 17 to 24 & 9 to 16 & 1 & 1 & 8 & 44 \\
\hline
\end{tabular}

Note: Possible type attributions for undiagnostic sherds are suggested within parentheses. Spits without tradeware ceramics are omitted.

Source: Authors' summary.

\section{Invertebrate faunal remains}

Recovered Leki Wakik marine and freshwater mollusc shell weight totals $4.8 \mathrm{~kg}$ across all test pits and includes 81 different taxa. Detailed assemblage data are provided in Table 5.A1 and Supplement 2 and are summarised here. Test Pit A contained a total shell weight of $907.4 \mathrm{~g}$ with a NISP of 769 and an MNI of 197. Test Pit B yielded $1325.6 \mathrm{~g}$ of shell (NISP = 543; MNI = 219). Test Pit C contained 973.39 g shell but only a NISP of 210 and an MNI of 88 . Test Pit D contained the least shell by weight, with $526.8 \mathrm{~g}$ and a NISP of 423 and an MNI of 177. Test Pit E contained a shell weight of $1046.8 \mathrm{~g}$, reaching a NISP of 461 and an MNI of 196.

Major marine and freshwater mollusc taxa for Leki Wakik included, in descending order (by MNI): Stenomelania sp. 1, Tarebia granifera, Turbo sp., Trochus sp., Stenomelania sp. 2, Cypraeidae, Conus sp., Turbo chrysostomus, Gibberulus gibberulus gibbosus, Thiara scabra and Turbo argyrostomus. Major family groups in descending order (by MNI) include Thiaridae, Turbinidae, Trochidae, Cypraeidae, Conidae and Strombidae.

Various habitats are represented (Table 5.3; dashes in the table indicate zero shells). Very minor contributions are from mangrove habitat species, which included Terebralia palustris (all test pits), T. sulcata (Test Pit A) and Geloina sp. (Test Pits A and E). No mangrove habitat shells were found below Spit 5 in any test pit. Freshwater species, likely sourced from the Laleia River, are more abundant than mangrove species (by all counts) and found throughout all squares in most spits. This included four species of small Thiaridae, common in other assemblages in Timor-Leste, including two unidentified but different species of Stenomelania-referred to here as Stenomelania sp. 1 and Stenomelania sp. 2. Also, Thiara scabra and Tarebia granifera were found. Additionally, one freshwater neritid is present in the assemblage: Septaria cf. luzonica. However, most species were from marine habitats from both reef and rocky intertidal areas and found throughout most spits in all squares. 
Table 5.3. Leki Wakik major mollusc taxa and habitat by spit. Counts shown are MNI.

\begin{tabular}{|c|c|c|c|c|c|c|c|}
\hline & \multicolumn{3}{|c|}{ Freshwater habitats } & \multicolumn{4}{|c|}{ Marine habitats } \\
\hline & Stenomelania sp. 1 & Tarebia granifera & Stenomelania sp. 2 & Conus sp. & Trochus sp. & Cypraeidae & Turbo sp. \\
\hline \multicolumn{8}{|c|}{ Test Pit A } \\
\hline Surface & - & - & - & - & - & $<1$ & - \\
\hline 1 & 36 & 19 & 7 & 8 & $<1$ & 1 & $<1$ \\
\hline 2 & 22 & 20 & 7 & 3 & 2 & 2 & 2 \\
\hline 3 & - & 2 & - & 3 & 4 & 2 & 2 \\
\hline 4 & 1 & - & - & $<1$ & $<1$ & 1 & $<1$ \\
\hline 5 & - & - & - & $<1$ & 1 & $<1$ & - \\
\hline 6 & 1 & - & - & - & $<1$ & - & $<1$ \\
\hline 7 & - & - & - & - & $<1$ & - & - \\
\hline 8 & - & - & - & - & - & - & - \\
\hline Total & 60 & 41 & 14 & 14 & 7 & 6 & 4 \\
\hline \multicolumn{8}{|c|}{ Test Pit B } \\
\hline 1 & 1 & - & - & - & - & - & - \\
\hline 2 & 2 & 2 & 1 & $<1$ & $<1$ & 1 & $<1$ \\
\hline 3 & 4 & 2 & 7 & 1 & 1 & 1 & 1 \\
\hline 4 & 7 & 1 & 2 & $<1$ & 1 & $<1$ & $<1$ \\
\hline 5 & 4 & 8 & 9 & 2 & - & 2 & - \\
\hline 6 & 1 & 8 & 4 & 1 & 1 & 1 & 1 \\
\hline 7 & 9 & 1 & 5 & $<1$ & $<1$ & $<1$ & 1 \\
\hline 8 & 1 & 15 & 1 & 1 & 1 & 1 & 3 \\
\hline 9 & 12 & 6 & 3 & $<1$ & $<1$ & $<1$ & $<1$ \\
\hline 10 & 5 & 3 & 2 & 1 & 2 & 1 & $<1$ \\
\hline 11 & 8 & 5 & 1 & 1 & 1 & 1 & 1 \\
\hline 12 & 2 & 1 & - & - & - & - & - \\
\hline 13 & - & - & - & - & - & - & - \\
\hline 14 & - & 1 & $<1$ & - & - & - & - \\
\hline Total & 56 & 53 & 35 & 7 & 7 & 8 & 7 \\
\hline \multicolumn{8}{|c|}{ Test Pit C } \\
\hline 1 & 3 & - & 3 & 2 & $<1$ & 2 & $<1$ \\
\hline 2 & $<1$ & - & $<1$ & - & 1 & $<1$ & 2 \\
\hline 3 & 1 & 5 & 1 & 1 & 1 & 1 & 1 \\
\hline 4 & 4 & 1 & 4 & 1 & & 1 & 2 \\
\hline 5 & 1 & 2 & 1 & - & 1 & 1 & $<1$ \\
\hline 6 & - & 1 & - & - & $<1$ & - & $<1$ \\
\hline 7 & $<1$ & 1 & $<1$ & - & - & - & - \\
\hline Total & 9 & 10 & 9 & 4 & 3 & 5 & 5 \\
\hline \multicolumn{8}{|c|}{ Test Pit D } \\
\hline 1 & 20 & 30 & 8 & $<1$ & 3 & $<1$ & 1 \\
\hline 2 & 7 & 3 & 6 & - & - & - & 3 \\
\hline 3 & 3 & 2 & 2 & - & 1 & 1 & - \\
\hline 4 & 3 & - & 2 & - & 1 & - & 1 \\
\hline 5 & - & - & - & - & 1 & - & - \\
\hline Total & 33 & 35 & 18 & $<1$ & 6 & 1 & 5 \\
\hline
\end{tabular}




\begin{tabular}{|c|c|c|c|c|c|c|c|}
\hline & \multicolumn{3}{|c|}{ Freshwater habitats } & \multicolumn{4}{|c|}{ Marine habitats } \\
\hline & Stenomelania sp. 1 & Tarebia granifera & Stenomelania sp. 2 & Conus sp. & Trochus sp. & Cypraeidae & Turbo sp. \\
\hline \multicolumn{8}{|c|}{ Test Pit E } \\
\hline 1 & - & - & - & - & - & - & - \\
\hline 2 & - & 1 & 1 & 1 & 1 & - & - \\
\hline 3 & 4 & 1 & 1 & 1 & $<1$ & - & - \\
\hline 4 & 26 & 21 & 5 & 1 & 1 & 2 & 1 \\
\hline 5 & 2 & 3 & 8 & 1 & 1 & 2 & - \\
\hline 6 & 2 & $<1$ & 2 & $<1$ & 1 & $<1$ & - \\
\hline 7 & - & - & - & - & 1 & - & - \\
\hline Total & 34 & 26 & 17 & 4 & 5 & 4 & 1 \\
\hline
\end{tabular}

Source: Authors' summary.

Potentially worked shell examples are present in the shell assemblage; they are, however, too weathered for definitive conclusions to be asserted. These included two samples of Melo sp. recovered from the surface of Test Pit A, one sample from Spit A3, and two samples from Spit E4. One sample of potentially worked nacre was found in Spit E5, and two cowrie shell dorsa were found in Spits B6 and C4. A Pyrene punctata shell was recovered from Spit B2, and one Architectonicidae from Spit E6; however, no use-wear traces were observed. These may have been intended as ornaments; they are small but very attractive shells.

Turning to the results from Test Pit B, marine and freshwater shell was commonly found between Spits 1-14 (Table 5.3). No clear temporal divide between freshwater and marine shell acquisition can be seen in this location, but the radiocarbon dates indicate that mangrove species are only represented between the seventeenth and nineteenth centuries. The type of mangrove-dwelling species present (T. palustris, T. sulcata, and Geloina sp.) points to Avicennia, Bruguiera or Ceriops mangroves, as opposed to Rhizophora forests (Mowat 1995).

\section{Vertebrate faunal remains}

The Leki Wakik test pits yielded 304 vertebrate bones, weighing a total of $323 \mathrm{~g}$. Specimen counts by taxa are shown in Table 5.4, while Supplement 2 lists taxa assignments by weight and spit. Dashes in the table indicate zero bone. Most bone was recovered from Test Pits $\mathrm{E}$ $(\mathrm{NISP}=112$, weight $=89 \mathrm{~g})$ and $\mathrm{B}(\mathrm{NISP}=106$, weight $=168 \mathrm{~g})$, with much smaller quantities from the other test pits.

Mammal remains dominate the bone assemblage (NISP $=288$ ), making up 95 per cent of total NISP and 99.7 per cent by weight. Most are medium to large mammals that could only be identified to class, though some of these could also be identified as medium and large bovids (Bovidae). Mammals are also the most diverse class in the bone assemblage, with five introduced domestic or commensal taxa identified to family, genus or species including water buffalo (Bubalus bubalis), goat/sheep (Caprinae), dog (Canis familiaris), pig (Sus cf. scrofa) and rat (Rattus sp.). Livestock, including goats and water buffalo, play an important role in Timorese socioeconomic systems today (Población 2013), and this appears to have been no different during the occupation at Leki Wakik. 
Table 5.4. Leki Wakik vertebrate NISP and unidentified specimens by spit.

\begin{tabular}{|c|c|c|c|c|c|c|c|c|c|c|c|c|c|c|c|c|c|c|}
\hline $\begin{array}{l}\text { Test pit } \\
\text { and spit }\end{array}$ & 음 & 든 & ֻ & 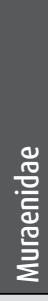 & 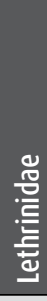 & $\begin{array}{l}\overline{\widetilde{D}} \\
\text { E్ } \\
\text { ऽ } \\
\end{array}$ & 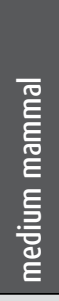 & 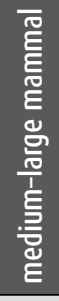 & $\begin{array}{l}\mathscr{0} \\
\overline{0} \\
0 \\
\end{array}$ & 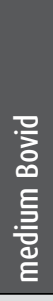 & 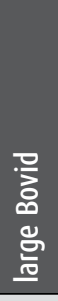 & $\begin{array}{l}\frac{.}{5} \\
\frac{5}{5} \\
\frac{5}{5} \\
\frac{5}{5} \\
\frac{5}{0}\end{array}$ & 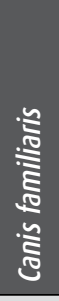 & . ్ㅡㄹ & 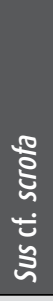 & 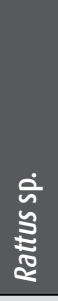 & 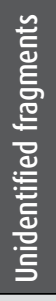 & Total \\
\hline \multicolumn{19}{|l|}{ A } \\
\hline 1 & - & - & - & - & - & - & 8 & - & 2 & - & - & - & - & - & - & - & - & 10 \\
\hline 2 & - & - & - & - & - & 5 & 5 & - & - & - & - & - & - & - & - & - & - & 10 \\
\hline 3 & - & 2 & - & - & - & - & 2 & - & - & - & 2 & - & - & - & - & - & - & 6 \\
\hline 4 & - & - & - & - & 1 & - & 2 & - & - & - & - & - & - & - & - & - & - & 3 \\
\hline A Total & - & 2 & - & - & 1 & 5 & 17 & - & 2 & - & 2 & - & - & - & - & - & - & 29 \\
\hline \multicolumn{19}{|l|}{ B } \\
\hline 1 & - & - & - & - & - & - & 1 & - & - & - & - & - & - & 1 & - & - & - & 2 \\
\hline 2 & - & - & - & - & - & 2 & 1 & - & - & - & - & - & - & - & - & - & - & 3 \\
\hline 3 & - & - & - & - & - & - & 4 & - & - & - & 20 & - & - & 6 & - & 1 & - & 31 \\
\hline 4 & - & - & - & - & - & 3 & - & - & - & - & - & - & - & - & - & - & - & 3 \\
\hline 5 & - & - & - & - & - & - & 1 & - & - & - & - & - & - & - & - & - & - & 1 \\
\hline 7 & - & - & - & - & - & 2 & - & 1 & - & - & 2 & 1 & - & - & - & - & - & 6 \\
\hline 8 & - & - & - & - & - & 12 & 2 & - & - & - & 34 & 2 & - & - & - & - & - & 50 \\
\hline 9 & - & - & - & - & - & - & 1 & - & - & - & - & - & - & - & - & - & - & 1 \\
\hline 10 & 1 & - & - & - & - & 3 & - & - & - & - & 3 & - & - & - & - & - & - & 7 \\
\hline 12 & - & - & - & - & - & - & 1 & - & - & - & - & - & 1 & - & - & - & - & 2 \\
\hline B Total & 1 & - & - & - & - & 22 & 11 & 1 & - & - & 59 & 3 & 1 & 7 & - & 1 & - & 106 \\
\hline \multicolumn{19}{|l|}{$C$} \\
\hline 1 & - & - & - & - & - & - & 1 & - & - & - & - & - & - & - & - & - & - & 1 \\
\hline 3 & - & - & - & - & - & - & 1 & 19 & - & - & - & - & - & - & - & - & - & 20 \\
\hline C Total & - & - & - & - & - & - & 2 & 19 & - & - & - & - & - & - & - & - & - & 21 \\
\hline \multicolumn{19}{|l|}{ D } \\
\hline 1 & - & - & - & - & - & - & 3 & - & - & - & - & - & - & - & - & - & - & 3 \\
\hline 2 & - & - & - & 3 & - & - & 9 & 1 & - & - & 2 & - & - & - & - & - & 4 & 19 \\
\hline 3 & - & - & - & - & - & - & 3 & - & - & - & - & - & 1 & - & - & - & - & 4 \\
\hline 4 & - & - & 1 & - & - & - & - & 4 & - & - & - & - & - & - & - & - & - & 5 \\
\hline 5 & - & - & - & - & - & 4 & - & - & - & - & - & - & - & - & 1 & - & - & 5 \\
\hline D Total & - & - & 1 & 3 & - & 4 & 15 & 5 & - & - & 2 & - & 1 & - & 1 & - & 4 & 36 \\
\hline \multicolumn{19}{|l|}{ E } \\
\hline 3 & - & - & - & - & - & - & 3 & - & - & - & - & - & - & - & - & - & - & 3 \\
\hline 4 & - & 3 & - & - & - & 73 & - & - & 1 & 1 & 6 & - & - & - & - & 1 & - & 85 \\
\hline 5 & - & 1 & - & - & - & - & - & 16 & - & - & - & - & - & - & 2 & - & - & 19 \\
\hline 6 & - & - & - & - & - & - & 3 & - & - & - & - & - & - & - & - & - & - & 3 \\
\hline 7 & - & - & - & - & - & 1 & - & - & - & - & - & - & - & 1 & - & - & - & 2 \\
\hline E Total & - & 4 & - & - & - & 74 & 6 & 16 & 1 & 1 & 6 & - & - & 1 & 2 & 1 & - & 112 \\
\hline Total & 1 & 6 & 1 & 3 & 1 & 105 & 51 & 41 & 3 & 1 & 69 & 3 & 2 & 8 & 3 & 2 & 4 & 304 \\
\hline
\end{tabular}

Source: Authors' summary. 
Three of the larger bovid teeth from Spits B7-B8 could be identified to water buffalo (Bubalus bubalis) based on size and shape, and the other large bovid remains (NISP = 69) distributed in Test Pits A, B, D and E probably also belong to this species. Water buffalo appear to have been introduced to Timor sometime in the last 1500 years, but likely predate Portuguese contact (Glover 1986; Amano and Piper 2011). The large bovid remains in this category consist of a crania maxilla, femur, metapodial, tibia, unidentified long bone and astragali fragments, none of which had any zones of epiphyseal fusion to record. Only two dog remains were recovered: a 2nd upper adult molar with only slight wear from Spit B12 and a calcaneus from Spit D3. Caprine remains (NISP $=8$ ) were concentrated in Spits B1-B3 with one other caprine bone in Spit E7. These consisted of mandibular fragments, a vertebra and teeth fragments. Pig remains present in Spits D5 and E5 are a cranium fragment and two mandibular tooth fragments. A Rattus cranium was recovered from Spit E4, and a mandible which is small enough to be Rattus exulans was present in Spit B3.

Non-mammalian faunal bones and teeth are quite sparsely represented in the assemblage. A single small bird (Aves) coracoid fragment from Spit B10 was only identifiable to class. Fish remains were distributed in small quantities in Test Pits A, D and E. Three families have been identified, including Scaridae (parrotfishes), Lethrinidae (emperor fishes), and Muraenidae (moray eels). Two moray eel dentaries were in Spit D2, a scarid quadrate was present in Spit D4, and a lethrinid tooth fragment was in Spit A4. Lethrinidae are voracious benthic carnivores, Scaridae are shallow reef herbivores, and moray eels are rocky shore benthic ambush predators. These taxa are predominately inshore marine reef fishes, which can be captured without the need for a boat using a variety of methods including hand lines, fish traps and gill net techniques that are commonly used by Timorese today (McWilliam 2002).

Seventeen bovid and medium to large mammal long bones, from Test Pits A, B, D and E, exhibit clear signs of obtuse and longitudinal smooth green fracture with impact scars consistent with butchery (chopping with heavy blade) practices. These include a large bovid femur from Spit A3 and a tibia from Spit B10, both of which were longitudinally split, possibly to remove marrow and grease. The possibility that these longitudinal fresh breaks could represent helical fractures caused by dog gnawing (Haynes 1983) was considered but crosschecking of bone surfaces for tell-tale signs of dog tooth marks (scoring and punctures) indicated that this was not the case. Bone flake fragments consistent with butchery were also recovered.

Four mammal long bones or cylinders, including single specimens of a large and a medium bovid, and two medium mammal specimens exhibited signs of carnivore gnawing. These cylinders typically had clear dog tooth puncture marks, compression marks and score marks indicating dogs had chewed the epiphyses off. Weathering was light on many of the bones, though three bones from Test Pits $\mathrm{C}$ and $\mathrm{E}$ do show signs of severe weathering, with noticeably extreme cracks with eroded fissures and exfoliated surfaces. None of the fish, bird or large bovid bones showed signs of burning but a number of medium to large mammal and one bovid (size unknown) bone, from Test Pits B, C, D and E, appear to be carbonised (NISP = 19), comprising 6.6 per cent of mammal bones. 


\section{Artefact patterns across classification types}

Having described the artefact attributes and patterns for each classification type, we now briefly consider artefact patterns across classification types and test pits. For this analysis, we will use depth (as represented by spit number) as a rough approximation of occupation period. That is, we will sometimes treat materials from the same spit number in different test pits as if they dated to roughly the same period. While we recognise this is hazardous in the absence of clear stratigraphic parallels, or more extensive radiocarbon dating, the patterns that emerge may help in understanding site features and indicate topics ripe for further investigation.

A few notable patterns are evident in the cumulative weight of artefacts across test pits (Figure 5.18). While most test pits increase fairly smoothly before levelling out, Test Pit B increases, and then levels out with relatively low artefact weights during Spits 5 and 6 before resuming a steep climb until Spit 10. The contrast with other spits is even more pronounced when comparing artefact weight densities across test pits (Figure 5.19). Both measures are dominated by marine shell, earthenware pottery and mammal bone weights; we will consider tradeware ceramics below, but other artefacts occur so rarely that they are of little utility for intrasite analyses. Test Pit B density by spit follows the same general pattern as other test pits through Spit 6, but then abruptly increases and artefacts continue until Spit 13. This might indicate that the sterile spits in the other test pits in fact are just interregnums in occupation and that artefacts may resume in deeper, unexcavated sediment. We note, however, that unlike the sterile layers in other test pits, Test Pit B did continue to have some artefacts in Spits 5 and 6, albeit at low weights. Alternatively, the patterns might indicate that the Test Pit B area was occupied earlier than other tested areas, with occupation intensity dropping before picking up again as the wider area was occupied. Since Test Pit B was associated with a stone wall, this might be a hint that the stone walls at the site predate the wider site occupation.

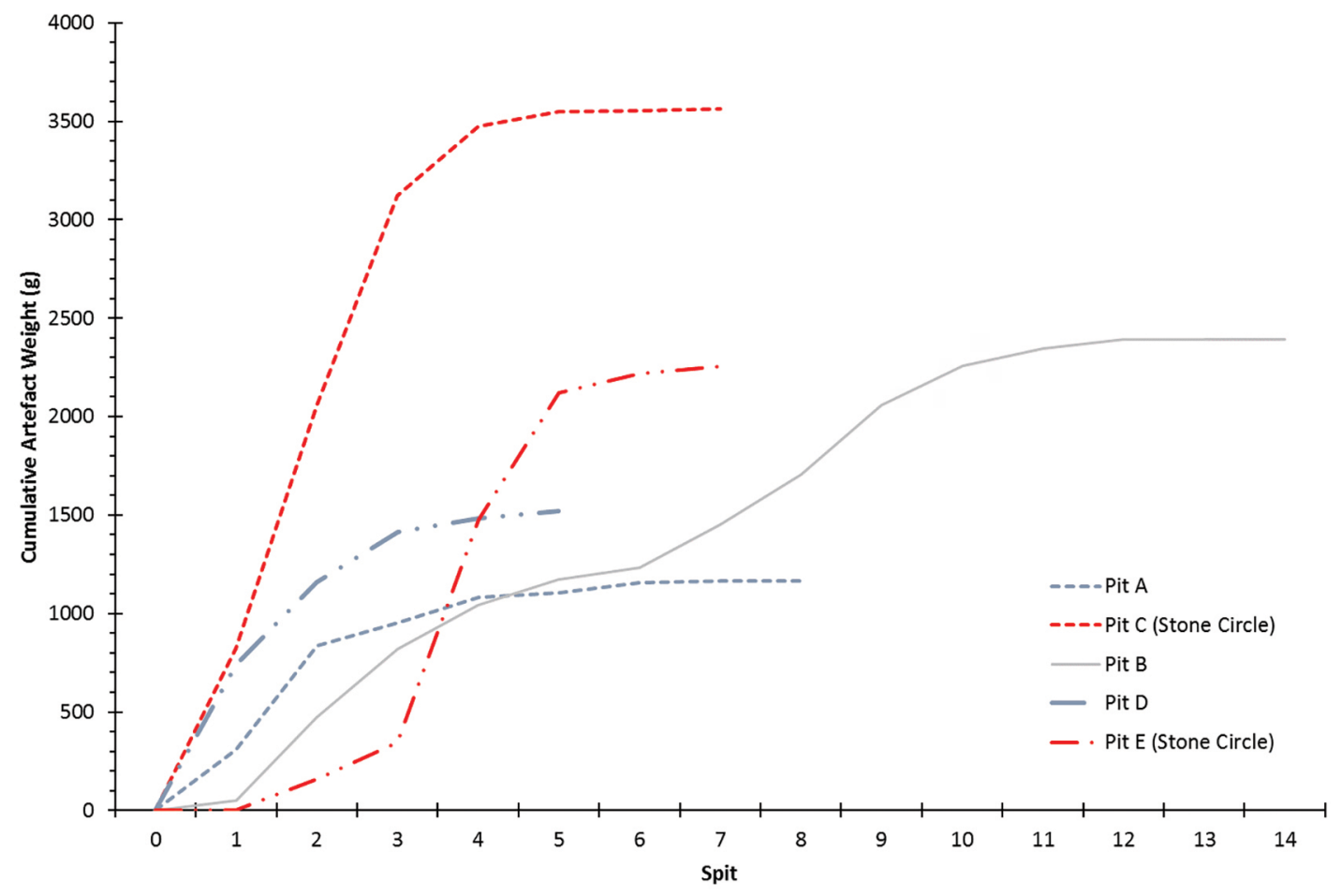

Figure 5.18. Leki Wakik cumulative artefact weight per spit.

Spit 0 is just a notional spit used to anchor the artefact curves.

Source: Jack Fenner. 


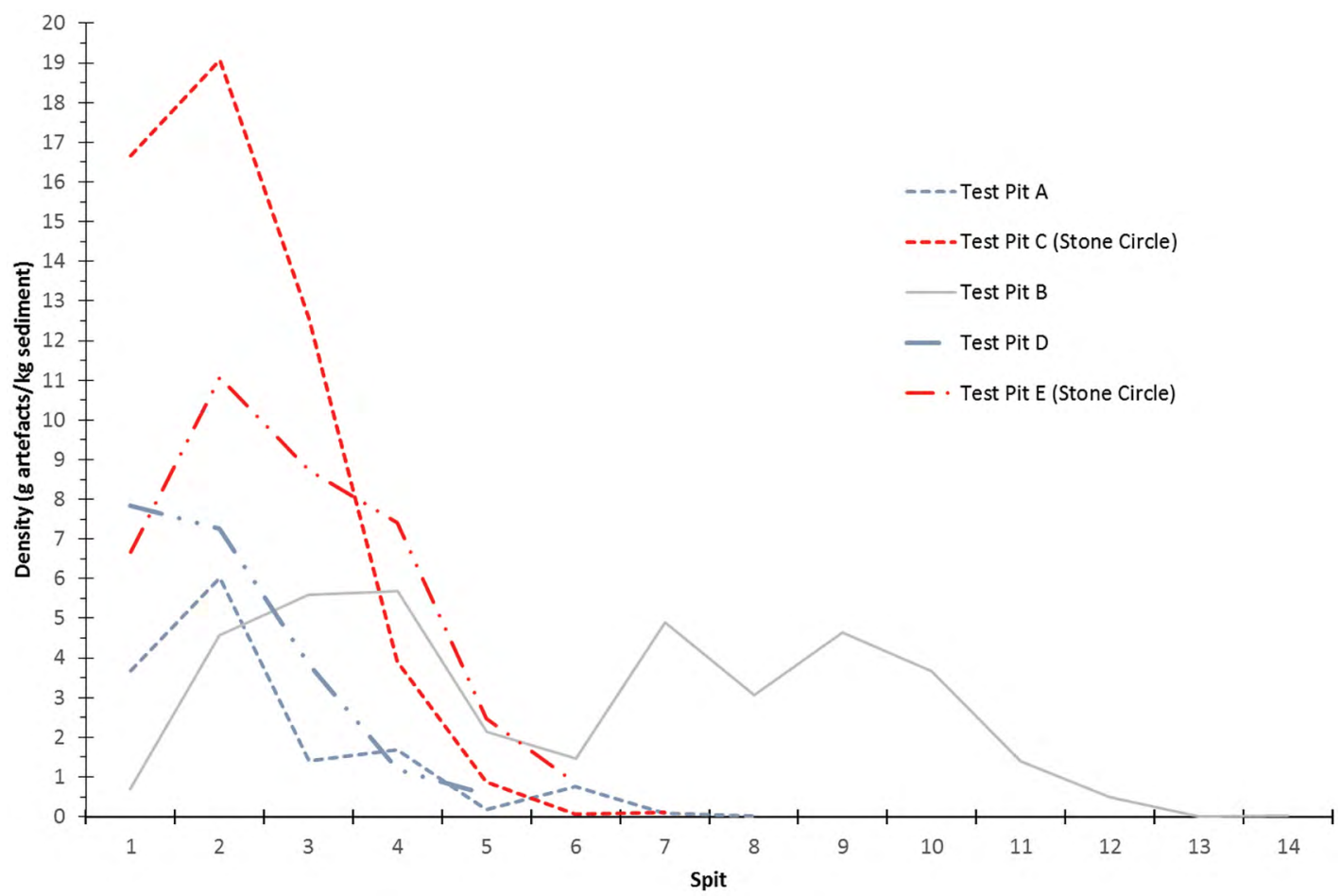

Figure 5.19. Leki Wakik artefact weight density per spit.

Density is computed as artefact weight $(\mathrm{g})$ /excavated sediment weight $(\mathrm{kg})$, excluding non-artefactual rocks.

Source: Jack Fenner.

A second pattern, evident in Figure 5.18 and Figure 5.19, is that the top levels of Test Pit C have higher weights and densities of artefacts than is the case for other test pits. This is due largely to a high amount of earthenware pottery in Spits 1 through 3, though marine mollusc shell is also unusually abundant in those spits (Table 5.A1). As Test Pit $\mathrm{C}$ is inside a stone circle, this might suggest that the stone circle areas were more densely occupied, or otherwise special places, during the relatively recent times represented by these spits. We note that Test Pit E, also located in a stone circle, has relatively high artefact weight density in its top spits, though the actual artefact weights are low (this contrast is explained by the very high abundance of non-artefactual stone in top levels of Test Pit E). Thus, there is some reason to believe that, at least during relatively recent times, the areas currently marked by stone

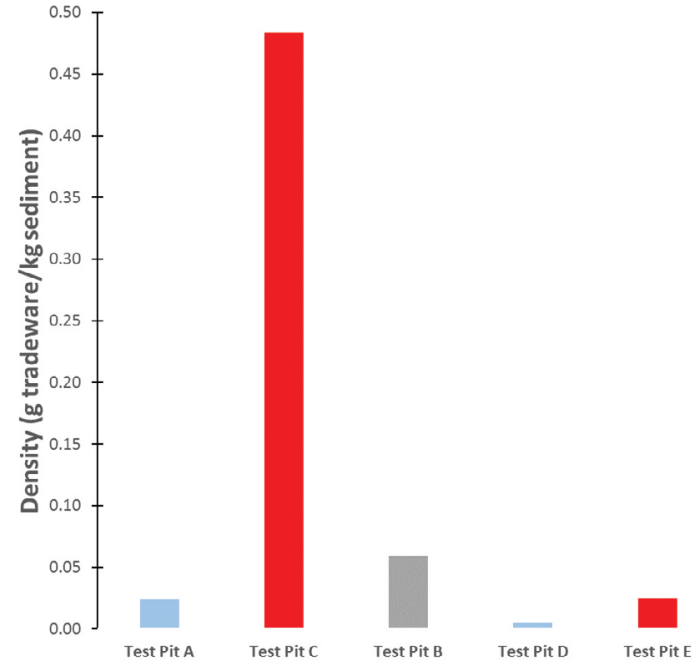

Figure 5.20. Leki Wakik tradeware density by test pit.

Red: Inside stone circle. Blue: Near stone circle. Source: Jack Fenner. 
Tradeware ceramics were a scarce, imported commodity that likely held special significance in Leki Wakik society and thus the tradeware sherd distribution within the site may indicate special or elite occupation spaces. While tradeware sherds were present in all test pits, they were concentrated in Test Pits C (48 per cent of recovered sherds) and B (34 per cent of recovered sherds) (Table 5.2). Tradeware sherds represent only about 7 per cent of the artefact weight in Test Pit C (Table 5.A1) so they are not a significant driver of its anomalously high artefact weight; instead they are another indication that the Test Pit $\mathrm{C}$ stone circle was a relatively special place. Test Pit E, the other stone circle site, produced only a single tradeware sherd. Test Pit B is adjacent to a large stone wall that partially encloses a relatively small area of the site, giving that area the appearance of being a special place. Its relatively high tradeware sherd count may support that assessment. It may be, however, that its abundance of tradeware is simply due to Test Pit B's much deeper excavation; relative to the amount of sediment excavated, tradeware does not appear to be especially abundant in Test Pit B (Figure 5.20).

\section{A fortified occupation site?}

A number of other hilltop sites in Timor-Leste have been interpreted as being fortified occupation sites. Sites such as Macapainara (Chapter 2, this volume), Vasino (Chapter 4, this volume) and Masui (O'Connor et al. 2012) share a number of characteristics: they are located on hilltops; are surrounded by high walls and/or cliffs (sometimes with large cacti on the perimeter); contain everyday artefacts, such as animal bone and earthenware pottery, as well as exotic tradeware ceramics; and have an initial occupation date after AD 1300, especially between 1550 and 1750 (O'Connor et al. 2012). Special dark stone slabs, usually associated with graves, are often present in fortified sites (McWilliam et al. 2012).

Leki Wakik shares all these characteristics with one significant exception: it is not surrounded by high walls or cliffs. It has two large walls positioned to cut off the central area from what we have called the northeastern and northwestern arms of the site (Figure 5.2). A third large wall runs along the perimeter for $19 \mathrm{~m}$ before turning in and partially enclosing a small portion of the site (including Test Pit B). However, unlike at the other sites noted above, these walls do not surround the site, spanning only about $150 \mathrm{~m}$ of the $775 \mathrm{~m}$ perimeter of the central portion of the site. Nor could the slopes around the site be considered to be cliffs; we routinely walked in zigzag fashion up the steepest slopes in the area-along the north and northeastern site boundaries - while carrying archaeological gear from the parking area. The eastern slopes could also be walked without much difficulty, and local herders routinely lead goats up the southern and western slopes. Leki Wakik is also distinguished from other hilltop sites by its size. With a central area of $31,000 \mathrm{~m}^{2}$ it dwarfs Vasino $\left(4690 \mathrm{~m}^{2}\right)$ and is more than twice the size of Masui $\left(13,830 \mathrm{~m}^{2}\right)$.

With such a large perimeter, which is mostly without stone fortification and surrounded by walkable slopes, it would have taken many hundreds if not several thousand people to defend it against even a fairly small attacking force that could pick its lines of approach. If that many people were available as a defence force, one suspects that even the minor advantages of its hilltop position and short stone walls would not have been necessary. It may be that some walls were disassembled and the stone reused after the site was abandoned, though neither the existing walls nor the stone circles have gaps suggesting partial disassembly. It is possible that the occupants simply did not have enough time to build more walls before abandoning the site, but the long radiocarbon sequence from Test Pit B indicates otherwise. It is also possible that the site was simply the best defensive position available to a particular group, so they made do as best they could. However, the lack of more and better positioned walls (cutting off the northeastern arm 
would seem a low priority compared to fortifying low slopes elsewhere) suggests instead that at Leki Wakik defence may not have been the top priority for site occupants. Occupying the hilltop may have had other cultural or environmental attributes that were sufficient to overcome difficulties related to access and exposure on a hilltop, such as offering an opportunity for elites to demonstrate their authority and their affinity with other elites. The presence of the large black stone that receives local offerings and the overall sacred nature of the site for contemporary residents of Laleia testify to the cultural importance of the location.

\section{Conclusions}

Surface mapping and excavation of $5 \mathrm{~m}^{2}$ cannot be expected to fully characterise such a large site, much less provide definitive answers to questions about site function or cultural intention. Nevertheless, our analyses do permit some tentative conclusions about the site. It clearly supported an occupation, with artefacts indicating that subsistence involved marine and freshwater resources as well as domesticated animal husbandry. Leki Wakik's occupants exploited gastropods and other shellfish from marine, estuarine and freshwater environments, though estuarine-based shells were relatively rare at Leki Wakik. There appears to be a shift towards more freshwater exploitation later in the site's history as freshwater gastropods were dominant in upper levels of Test Pits A and $\mathrm{D}$ and in the middle levels of E. Minor numbers of mangrove species appear for the first time in the upper levels, perhaps indicating a late formation of this ecosystem locally. The species of estuarine shellfish gathered indicates that landward rather than seaward mangrove forests were being exploited (Australian National Botanic Gardens 2019). Throughout the occupation of the site, the residents also consistently harvested marine species, which were found in all spits.

Given its location near the coast, there were surprisingly few fish remains at Leki Wakik. However, the presence of dog bones and dog-gnawed bones suggests that most discarded fish remains may have been consumed by dogs, much like they were at the Vasino fort site (Amano and Piper 2011; Chapter 4, this volume). The fish taxa that are represented are predominately inshore marine reef fishes, which can be captured without the need for a boat using a variety of methods including hand lines, fish traps, and gill net techniques that are commonly used by the Timorese today (McWilliam 2002).

Domestic livestock, including water buffalo, pigs and goats, continue to play an important role in Timorese socioeconomic systems (Población 2013). This also appears to have been the case during the occupation of Leki Wakik, which contained all these species, as well as commensal dogs and rats. It may be significant that no definitively wild mammal species' remains were found. Historical documents and local oral traditions indicate that, at times, relations between clan groups were characterised by internecine warfare and hostilities, which may have made it dangerous for hunters to pursue wild game. However, in the late nineteenth and early twentieth centuries, and particularly after the 1912 Timorese rebellion led by Dom Boaventura (the indigenous ruler of Manufahi or Same), the Portuguese introduced a program to move Timor-Leste people from 'hunter-gathering and shifting forms of agriculture to permanent gardens and other more sedentary forms of cultivation' (Fitzpatrick 2002:35), which indicates that some level of hunting was still widely practised in Timor-Leste at that time. In addition, wild game remains were recovered from the fortified sites of Macapainara and Ira Ara in the Com area to the east (see Chapters 2 and 3, this volume) and from Manatuto to the west (Lape and Chao 2008). Thus, it is surprising that wild game remains were not recovered from Leki Wakik. 
At least a portion of the site must have been occupied for centuries, perhaps starting around $\mathrm{AD}$ 1450. The presence of tradeware from the lowest levels of the Leki Wakik excavations indicates that its occupants had some form of contact, whether direct trade or exchange, with the outside world from its formation. The lack of wasters at Leki Wakik indicates that pottery manufacture likely did not occur at this location and also implies the existence of local exchange networks. However, some of our senior male informants knew how to make pottery utensils and they recalled using locally made pottery utensils in their youth, and there is no evidence to suggest that the earthenware was imported rather than locally made at a nearby location.

Oral history and the lack of a substantial amount of historical material at the site indicate that the site was abandoned prior to the local widespread availability of Western goods. Although the site contains some stone walls and is located on a hilltop, its role as a defensive fortification is questionable. While the wall layout suggests that the area near Test Pit B partially enclosed by stone walls was a special area-perhaps an elite residence-the artefacts recovered from that pit do not seem out of the ordinary. If there was a special place revealed during excavations, it is the stone circle containing Test Pit $\mathrm{C}$, which produced both an unusual abundance of artefacts and a high number of exotic tradeware sherds. In fact, both excavated stone circles yielded a higher artefact abundance than did nearby areas, indicating the stone circles mark areas of some special significance or more intensive occupation.

\section{Supplemental material}

Supplemental information is provided separately via the ANU Open Research Library and the ANU Data Commons.

Supplement 1, ANU Open Research Library:

- Lim, T.S. 2017. Report on high-fired glazed ceramics at Leki Wakik, East Timor. hdl.handle. net/1885/159483. Adobe PDF format. Unpublished report. The Australian National University, Canberra.

Supplement 2, ANU Data Commons:

- Leki Wakik artefact data sheets. dx.doi.org/10.25911/5cb55b75057a4.

Excel 2010 files in zipped format. Includes:

- LekiWakik_RecoveredMaterial_v2.xlsx

- Leki Wakik Square B Ceramics_Supps.xlsx

- Leki Wakik Shell Supplementary Information (1)_Summarised.xlsx

- LekiWakik_VertebrateData.xlsx 


\section{References}

Amano, N. and P.J. Piper 2011. A report on the animal remains from the 2009 archaeological excavations at Vasino in East Timor. Unpublished report. The Australian National University, Canberra. hdl.handle. net/1885/111565. Accessed 19 March 2020.

Australian National Botanical Gardens 2019. Mangroves. Australian vegetation: Information about Australia’s flora. www.anbg.gov.au/photo/vegetation/mangroves.html. Accessed 19 March 2020.

Behrensmeyer, A.K. 1978. Taphonomic and ecologic information from bone weathering. Paleobiology 4(2):150-162. doi.org/10.1017/s0094837300005820.

Boxer, C.R. 1948. Fidalgos in the Far East, 1550-1770. Martinus Nijhoff, The Hague.

Bronk Ramsey, C. 2009. Bayesian analysis of radiocarbon dates. Radiocarbon 51:337-360. doi.org/ $10.1017 /$ s0033822200033865.

Classen, C. 1998. Shells. Cambridge University Press, Cambridge.

Coil, R., M. Tappen and K. Yezzi-Woodley 2017. New analytical methods for comparing bone fracture angles: A controlled study of hammerstone and hyena (Crocuta crocuta) long bone breakage. Archaeometry 59(5):900-917. doi.org/10.1111/arcm.12285.

Davidson, K.G. 1994. The Portuguese colonisation of Timor: The final stage, 1850-1912. Unpublished $\mathrm{PhD}$ thesis. University of Melbourne, Melbourne.

Fitzpatrick, D. 2002. Land claims in East Timor. Asia Pacific Press, Canberra.

Galán, A.B., M. Rodríguez, S. De Juana and M. Domínguez-Rodrigo 2009. A new experimental study on percussion marks and notches and their bearing on the interpretation of hammerstone-broken faunal assemblages. Journal of Archaeological Science 36:776-784.

Glover, I. 1986. Archaeology in Eastern Timor, 1966-67. Terra Australis 11. Department of Prehistory, Research School of Pacific Studies, The Australian National University, Canberra.

Gunn, G.C. 1999. Timor Loro Sae: 500 years. Livros do Oriente, Macau.

Haynes, G. 1983. Frequencies of spiral and green-bone fractures on ungulate limb bones in modern surface assemblages. American Antiquity 48:102-114. doi.org/10.2307/279822.

Hogg, A.G., Q. Hua, P.G. Blackwell, M. Niu, C.E. Buck, T.P. Guilderson, T.J. Heaton, J.G. Palmer, P.J. Reimer, R.W. Reimer, C.S.M. Turney and S.R.H. Zimmerman 2013. SHCal13 Southern Hemisphere calibration, 0-50,000 years cal BP. Radiocarbon 55:1889-1903. doi.org/10.2458/ azu_js_rc. 55.16783 .

Joliffe, J. 1978. East Timor: Nationalism and colonialism. University of Queensland Press, St Lucia.

Lape, P.V. and C.-Y. Chao 2008. Fortification as a human response to late Holocene climate change in East Timor. Archaeology in Oceania 43(1):11-21. doi.org/10.1002/j.1834-4453.2008.tb00026.x.

Lyman, R.L. 2008. Quantitative paleozoology. Cambridge University Press, Cambridge.

McWilliam, A. 2000. A plague on your house? Some impacts of Chromolaena odorata on Timorese livelihoods. Human Ecology 28(3):451-469. doi.org/10.1023/A:1007061632588.

McWilliam, A. 2002. Timorese seascapes: Perspectives on customary marine tenures in East Timor. The Asia Pacific Journal of Anthropology, 3(2):6-32. doi.org/10.1080/14442210210001706266. 
McWilliam, A. 2007. Looking for Adê: A contribution to Timorese historiography. Bijdragen tot de Taal-, Land-en Volkenkunde 163(2/3):221-238. doi.org/10.1163/22134379-90003684.

McWilliam, A., D. Bulbeck, S. Brockwell and S. O’Connor 2012. The cultural legacy of Makassar stone in East Timor. The Asia Pacific Journal of Anthropology 13(3):262-279. doi.org/10.1080/14442213. 2012.674054 .

Mowat, F. 1995. Variability in Western Arnhem Land midden deposits. Unpublished Masters thesis. Northern Territory University, Darwin.

O'Connor, S., A. McWilliam, J.N. Fenner, and S. Brockwell 2012. Examining the origin of fortifications in East Timor: Social and environmental factors. Journal of Island and Coastal Archaeology 7:200-218. doi:10.1080/15564894.2011.619245.

Pannell, S. 2006. Welcome to the Hotel Tutuala: Fataluku accounts of going places in an immobile world. The Asia Pacific Journal of Anthropology 7(3):203-219. doi.org/10.1080/14442210600965158.

Población, E.A. 2013. Fisheries and food security in Timor-Leste: The effects of ritual meat exchanges and market chains on fishing. Food Security 5:807-816. doi.org/10.1007/s12571-013-0308-2.

Reimer, P., E. Bard, A. Bayliss, J.W. Beck, P.G. Blackwell, C.B. Ramsey, P.M. Grootes, T.P. Guilderson, H. Haflidason, I. Hajdas, C. Hatté, T.J. Heaton, D.L. Hoffmann, A.G. Hogg, K.A. Hughen, K.F. Kaiser, B. Kromer, S.W. Manning, M. Niu, R.W. Reimer, D.A. Richards, E. Marian Scott, J.R. Southon, R.A. Staff, C.S.M. Turney and J. van der Plicht 2013. IntCal13 and Marine13 radiocarbon age calibration curves 0-50,000 years cal BP. Radiocarbon 55:1869-1887. doi.org/ 10.2458/azu_js_rc.55.16947.doi.org/10.2458/azu_js_rc.55.16947.

Roque, R. 2010. Headhunting and colonialism: Anthropology and the circulation of human skulls in the Portuguese Empire 1870-1930. Palgrave Macmillan, New York.

Sadek-Kooros, H. 1975. Intentional fracturing of bone: Description of criteria. In A.T. Clason (ed.), Archaeozoological studies. North Holland Publishing, Amsterdam.

Shepard, A.O. 1974. Ceramics for the archaeologist. Carnegie Institution Publications, Washington D.C.

Shipman, P., G. Foster and M. Schoeninger 1984. Burnt bones and teeth: An experimental study of color, morphology, crystal structure and shrinkage. Journal of Archaeological Science 11(4):307-325. doi.org/10.1016/0305-4403(84)90013-x.

Stiner, M.C., S.L. Kuhn, S. Weiner and O. Bar-Yosef 1995. Differential burning, recrystallization, and fragmentation of archaeological bone. Journal of Archaeological Science 22:223-237. doi.org/10.1006/ jasc. 1995.0024.

White, J., and W. Henderson 2003. Pottery anatomy: Review and selection of basic nomenclature as a step toward a searchable rim form database for the Sakon Nakhon Basin. Bulletin of the Indo-Pacific Prehistory Association 23:35-49. 


\section{Appendix}

\begin{tabular}{|c|c|c|c|c|c|c|c|c|c|c|c|c|c|c|c|c|c|c|c|c|c|c|c|}
\hline 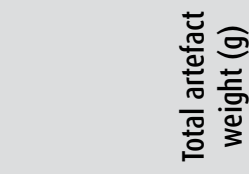 & $\begin{array}{l} \\
\ddot{b} \\
\stackrel{0}{ } \\
\text { pे }\end{array}$ & స్. & $\begin{array}{l}\hat{\sigma} \\
\bar{\sigma}\end{array}$ & $\frac{\hat{m}}{m}$ & 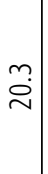 & $\underset{\dot{E}}{\check{n}}$ & $\stackrel{\infty}{\sim}$ & $\stackrel{ా}{\circ}$ & $\begin{array}{l}\hat{0} \\
\stackrel{0}{\sigma}\end{array}$ & \begin{tabular}{l|l|}
$b$ \\
$\dot{q}$ \\
$\dot{q}$
\end{tabular} & & $\underset{m}{\check{m}}$ & $\underset{\gtrsim}{\stackrel{2}{\pi}} \underset{\pi}{\pi}$ & 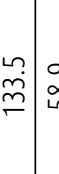 & 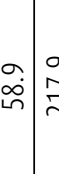 & 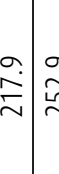 & 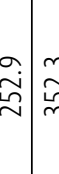 & 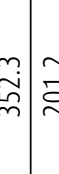 & 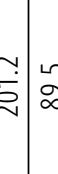 & 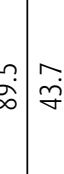 & 0 & $\bar{\sim}$ & 衣 \\
\hline |elaw & 1 & & 1 & 1 & 1 & 1 & I & 1 & & 1 & 1 & 1 & 1 & 1 & 1 & 1 & 1 & 1 & 1 & \begin{tabular}{l|l}
1 & 1
\end{tabular} & 1 & 1 & 0 \\
\hline כ & 1 & $\stackrel{6}{\stackrel{0}{\sim}}$ & 1 & 1 & 1 & 1 & 1 & 1 & 完 & 1 & 1 & 1 & 1 & 1 & 1 & 1 & 1 & 1 & ' & ' & 1 & 1 & 0 \\
\hline pəӘS & 1 & 1 & 1 & 1 & 1 & 1 & I & 1 & & $\begin{array}{l}m \\
0\end{array}$ & 1 & 1 & 1 & 1 & 1 & 1 & 1 & 1 & ' & \begin{tabular}{l|l}
1 & 1
\end{tabular} & 1 & 1 & $\tilde{n}$ \\
\hline 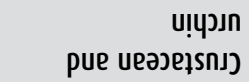 & $\overline{0}$ & 1 & $\grave{o}$ & m. & & $\widetilde{o}$ & & & $\stackrel{\sim}{\sim}$ & 1 & 1 & 1 & 1 & 1 & 1 & 1 & 1 & 1 & ' & 5 & 1 & 1 & $\check{0}$ \\
\hline วu0q पS!」 & 1 & 1 & $\overline{0}$ & $\dot{\sigma}$ & 1 & 1 & 1 & 1 & $\tilde{o}$ & 1 & 1 & 1 & 1 & 1 & 1 & 1 & 1 & 1 & ' & 1 & 1 & ' & 0 \\
\hline әu0q pנ!g & 1 & 1 & 1 & 1 & 1 & I & 1 & 1 & & 1 & I & 1 & 1 & 1 & \begin{tabular}{l|l}
1 & 1 \\
1
\end{tabular} & 1 & \begin{tabular}{l|l}
1 & 1
\end{tabular} & . & $\begin{array}{lll} & 1 \\
& & 1\end{array}$ & \begin{tabular}{l|l}
1 & 1
\end{tabular} & 1 & 1 & $\stackrel{\sim}{0}$ \\
\hline әU0q ןешسеW & $\sim$ & $\stackrel{\vec{m}}{m}$ & $\stackrel{\nabla}{\stackrel{\sim}{\sim}}$ & $\dot{\sigma}$ & 1 & 1 & I & 1 & å̀. & ठே. & $\underset{\sim}{\triangleleft}$ & $\begin{array}{l}\sigma \\
\grave{m} \\
m\end{array}$ & \begin{tabular}{l|l}
0 \\
0
\end{tabular} & $\stackrel{\infty}{-}$ & 10 & 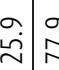 & م̦ & $\begin{array}{ll}m & 9 \\
0 & 7\end{array}$ & - & $1 \stackrel{1}{=}$ & \begin{tabular}{lll} 
\\
\hdashline & 1
\end{tabular} & 1 & $\begin{array}{c}\tilde{1} \\
\infty \\
0 \\
0\end{array}$ \\
\hline $\begin{array}{r}\text { ग!шелә } \\
\text { (рәzеןб) әлемәреј }\end{array}$ & $\stackrel{\nabla}{\rightleftharpoons}$ & $\stackrel{\nabla}{\forall}$ & 1 & 1 & I & 1 & 1 & 1 & $\begin{array}{l}\infty \\
\stackrel{\infty}{ } \\
\stackrel{\infty}{ }\end{array}$ & 1 & $\stackrel{a}{m}$ & ○. & $\underset{\infty}{+}$ & & - & $\begin{array}{l}0 \\
\dot{\nu}\end{array}$ & a & 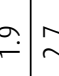 & vi & 5 & 1 & 1 & 유 \\
\hline 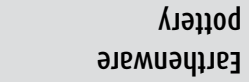 & 1 & 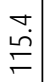 & $\stackrel{子}{\sigma}$ & $\stackrel{a}{\curvearrowright}$ & $\dot{m}$ & & $\underset{\sim}{\sim}$ & 1 & $\begin{array}{l}\infty \\
\dot{\infty} \\
\infty\end{array}$ & $\widehat{\sim}$ & $\stackrel{m}{r}$ & $\begin{array}{ll}m & \\
\stackrel{m}{\sigma} & 1\end{array}$ & \begin{tabular}{l|l}
$\infty$ & 0 \\
$\infty$ & 0
\end{tabular} & \begin{tabular}{l|l}
$\infty$ & 1 \\
$\infty$ & 0 \\
$\infty$ & 0
\end{tabular} & 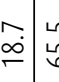 & 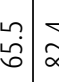 & 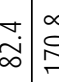 & 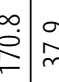 & ra & 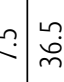 & $\begin{array}{ll}? \\
?\end{array}$ & - & $\frac{a}{n}$ \\
\hline [eJ0] & 1 & $\subsetneq$ & $\hat{0}$ & 1 & I & I & I & I & 車 & 1 & 1 & 1 & 1 & 1 & I & 1 & 1 & I & I & । & 1 & 1 & 0 \\
\hline 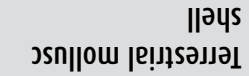 & 1 & 1 & 1 & 1 & 1 & I & I & 1 & 0 & 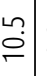 & 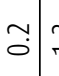 & $m$ & $1 / 2$ & $\hat{\circ}$ & 1 & 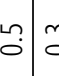 & $\begin{array}{l}m \\
0\end{array}$ & 1 & 1 & 1 & 1 & 1 & $\stackrel{\sim}{m}$ \\
\hline 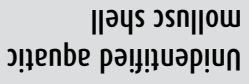 & $\underset{\infty}{\sim}$ & $\underset{\infty}{\sim}$ & $\overline{6}$ & $\begin{array}{l}\ddot{0} \\
\ddot{r}\end{array}$ & $\stackrel{\sim}{\sim}$ & $\lesssim$ & 1 & 1 & $\begin{array}{l}m \\
\dot{0} \\
\leftarrow\end{array}$ & $\bar{\searrow}$ & 官 & $\begin{array}{l}0 \\
\stackrel{\infty}{\sim}\end{array}$ & $\bar{b}$ & $\begin{array}{lll}m & \\
\grave{1} & & \end{array}$ & $\mp \approx$ & 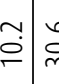 & 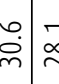 & $\stackrel{7}{i}$ & 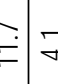 & $\dot{\sim} \stackrel{\sim}{\sim}$ & $\begin{array}{ll} \\
\text { i }\end{array}$ & Ðே. & $\begin{array}{c}\mathfrak{\infty} \\
\infty \\
\infty\end{array}$ \\
\hline 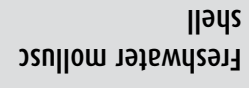 & $\widetilde{\sigma}$ & $\begin{array}{l}0 \\
\text { aे } \\
\text { जे }\end{array}$ & $\stackrel{m}{\sim}$ & $\stackrel{0}{0}$ & 1 & 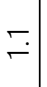 & I & 1 & $\stackrel{n}{\check{\sim}}$ & $\underset{0}{\sim}$ & $\stackrel{\sim}{\sim})$ & $\stackrel{a}{i}$ & $\begin{array}{l}m \\
m\end{array}$ & aे & $\underset{\sim}{2}$ & $\underset{+}{\check{\leftarrow}}$ & 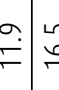 & 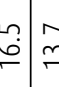 & $\vec{r}$ & $\stackrel{n}{?}$ & & $\hat{\sigma}^{\circ}$ & $\underset{\infty}{+}$ \\
\hline 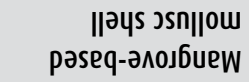 & $\stackrel{\bullet}{\dot{\sim}}$ & $\stackrel{\infty}{\sim}$ & 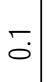 & 1 & I & I & I & 1 & 年 & 1 & $\hat{0}$ & 1 & 1 & 1 & 1 & 1 & 1 & I & I & I & 1 & 1 & $\tilde{0}$ \\
\hline 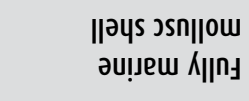 & 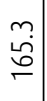 & $\stackrel{m}{m}$ & $\stackrel{\sim}{\dddot{\gamma}}$ & $\begin{array}{l}a \\
\infty \\
\infty\end{array} \mid$ & $\stackrel{\bullet}{ \pm}$ & г.'. & 官 & 1 & $\frac{-}{6}$ & 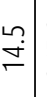 & 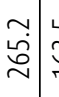 & $\begin{array}{l}\stackrel{n}{2} \\
\tilde{n}=\end{array}$ & 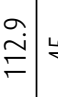 & $\stackrel{\sim}{\forall}$ & $\stackrel{7}{2}$ & $\underset{\infty}{\check{\infty}}$ & ֻே & 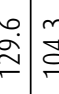 & 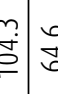 & 苞 & $\begin{array}{l}P \\
\end{array}$ & 1 & $\begin{array}{l}\infty \\
\dot{0} \\
0 \\
0 \\
\end{array}$ \\
\hline 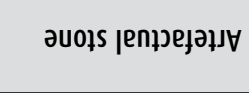 & $m$ & n. & $\hat{0}$ & ma & I & I & I & $\stackrel{\circ}{\circ}$ & 官 & 1 & I & 1 & பே. & 1 & 1 & 1 & $\begin{array}{c}m \\
0\end{array}$ & $\tau i$ & $\begin{array}{l}\infty \\
\sim \\
\sim\end{array}$ & -1 & 1 & 1 & $\begin{array}{l}0 \\
\sigma \\
\sigma\end{array}$ \\
\hline 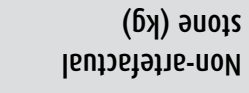 & $\stackrel{a}{\sigma}$ & $\hat{\vartheta}$ & $\stackrel{\sim}{\mathscr{q}}$ & $\hat{m}$ & $\stackrel{\text { ㄴ? }}{\dot{\gamma}}$ & $\hat{a}$ & $\begin{array}{l}a \\
\dot{g}\end{array}$ & \begin{tabular}{l|}
$\dot{\varphi}$ \\
$\dot{f}$
\end{tabular} & 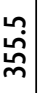 & $\frac{a}{z}$ & 12 & $\underset{\underset{\forall}{\forall}}{\stackrel{m}{*}}$ & $\begin{array}{c}m \\
\infty\end{array}$ & 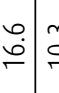 & \begin{tabular}{l|l}
$m$ & $\alpha$ \\
$\stackrel{m}{r}$ & $m$
\end{tabular} & $\begin{array}{l}\infty \\
\dot{m} \\
\dot{m}\end{array}$ & $\underset{m}{\stackrel{N}{m}}$ & $\check{\sim}^{\circ}$ & 1 & \begin{tabular}{c|c}
$c$ & 0 \\
$\infty$ & $\stackrel{n}{m}$
\end{tabular} & : & । & 官 \\
\hline (Бү) фuәш!рәS & $\begin{array}{l}m \\
m \\
\infty\end{array}$ & $\infty$ & 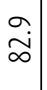 & $\infty$ & $\begin{array}{l}0 \\
\stackrel{0}{0} \\
\end{array}$ & $\frac{\varrho}{\Sigma}$ & $\underset{\infty}{\tilde{\infty}}$ & $\begin{array}{l}0 \\
\underset{\mathbb{V}}{ }\end{array}$ & 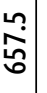 & $\stackrel{\Gamma}{\Sigma}$ & $\underset{\check{\sigma}}{\check{\sigma}}$ & 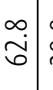 & \begin{tabular}{c|r}
$\infty$ & \\
$\infty$ & \\
$m$ &
\end{tabular} & $\underset{\mathbb{v}}{ }$ & 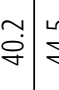 & $\begin{array}{lll}\stackrel{n}{\forall} \\
\dot{f}\end{array}$ & $\underset{\infty}{i} \mid \stackrel{n}{i}$ & $0 \frac{9}{5}$ & 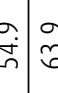 & \begin{tabular}{c|c}
$\qquad$ & $\infty$ \\
$b$ & $\infty$ \\
\end{tabular} & \begin{tabular}{l|l}
0 \\
0 \\
0 \\
0
\end{tabular} & $\frac{a}{z}$ & $\stackrel{\infty}{\infty}$ \\
\hline c & - & $\sim$ & $m$ & $\nabla$ & 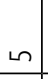 & 6 & $\Lambda$ & $\infty$ & 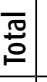 & - & $\sim r$ & $m \cdot$ & $\nabla L$ & $\operatorname{Ln} v$ & \begin{tabular}{l|l}
0 & 4 \\
\end{tabular} & $\wedge \alpha$ & $\infty \quad 0$ & $a$ & 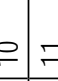 & $=\simeq$ & $=m$ & 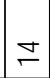 & 吾 \\
\hline 氚 & $<$ & $<$ & $<$ & $<$ & $<$ & $<$ & $\varangle$ & $\varangle$ & $<$ & $\infty$ & $\infty \quad c$ & $\infty$ & $\infty \quad 0$ & $\infty \quad 0$ & $\infty \quad \propto$ & $\infty \quad \propto$ & 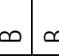 & $\infty$ & ص & $\infty$ & \begin{tabular}{l|l}
$\infty$ & $\infty$ \\
\end{tabular} & $\infty$ & $\infty$ \\
\hline
\end{tabular}




\begin{tabular}{|c|c|c|c|c|c|c|c|c|c|c|c|c|c|c|c|c|c|c|c|c|c|c|c|}
\hline 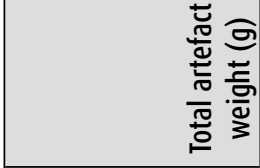 & $\underset{m}{m}$ & $\begin{array}{l}\tilde{N} \\
\tilde{\Xi} \\
\end{array}$ & 竎 & \begin{tabular}{|l|}
$\stackrel{L}{L}$ \\
$\stackrel{5}{m}$ \\
$m$
\end{tabular} & $\stackrel{m}{N}$ & $\stackrel{\sim}{\sim}$ & ฟָ) & 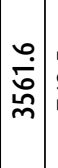 & $\begin{array}{l}\stackrel{\llcorner}{m} \\
\stackrel{\sim}{N}\end{array}$ & 产 & $\stackrel{\nabla}{\sim}$ & $\frac{⿱}{i}$ & $\mid \begin{array}{l}\dot{0} \\
\dot{m}\end{array}$ & $\mid \begin{array}{l}0 \\
\infty \\
\infty \\
\\
\end{array}$ & & $\frac{m}{6}$ & $\begin{array}{c}a \\
\tilde{m} \\
\infty \\
\infty\end{array}$ & 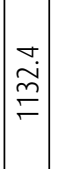 & $\left|\begin{array}{l}\infty \\
\ddot{m} \\
\tilde{b} \\
\end{array}\right|$ & a & $\overline{\dot{m}}$ & 哭 & $\begin{array}{l}\infty \\
0 \\
\dot{\dot{j}} \\
0 \\
0\end{array}$ \\
\hline ןеiәW & 1 & เก & 1 & 1 & 1 & 1 & 1 & in & 1 & 1 & 1 & 1 & 1 & 0 & 1 & 1 & 1 & 1 & 1 & 1 & 1 & 0 & in \\
\hline әॄวगบ0) & 1 & I & I & 1 & 1 & 1 & 1 & 0 & 1 & 1 & 1 & 1 & 1 & 0 & 1 & I & 1 & 1 & I & 1 & 1 & 0 & $\begin{array}{l}0 \\
\\
\end{array}$ \\
\hline pəəs & 1 & I & 1 & 1 & 1 & 1 & 1 & 0 & 1 & 1 & 1 & 1 & 1 & 0 & 1 & $\nabla$ & $\stackrel{\sim}{\leftarrow}$ & \begin{tabular}{|l|l|}
$n$ \\
0
\end{tabular} & 1 & 1 & 1 & aे & $\tilde{\omega}$ \\
\hline 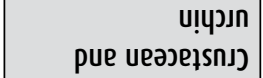 & I & 1 & 1 & 1 & 1 & 1 & 1 & 0 & $\overline{0}$ & $\dot{0}$ & $\check{0}$ & ' & 1 & $\hat{m}$ & 1 & 1 & 1 & 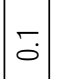 & $\mathscr{0}^{\circ}$ & 1 & 1 & $\hat{0}$ & 兄 \\
\hline วu0q Чs!] & ' & 1 & 1 & 1 & 1 & 1 & 1 & 0 & 1 & 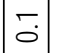 & 1 & $\tilde{0}$ & । & $\tilde{a}$ & 1 & 1 & 1 & m. & б. & 1 & 1 & $\ddot{0}$ & ó \\
\hline әи०q pग!g & 1 & I & I & I & 1 & 1 & 1 & 0 & 1 & 1 & 1 & 1 & 1 & 0 & 1 & 1 & 1 & 1 & 1 & 1 & 1 & 0 & $\mid \begin{array}{c}n \\
0\end{array}$ \\
\hline วч0q |ewwew & $\stackrel{2}{0}$ & I & $\stackrel{\infty}{\stackrel{\infty}{\sim}}$ & 1 & 1 & 1 & 1 & $\stackrel{m}{m}$ & $\stackrel{m}{-}$ & $\bar{\sim}$ & $\stackrel{\varrho}{-}$ & $\stackrel{m}{m}$ & $\bar{m}$ & ọ: & 1 & I & $\underset{\sim}{\sim}$ & $\stackrel{2}{\Omega}$ & \begin{tabular}{|l|}
$\infty$ \\
0 \\
0
\end{tabular} \mid & - & $\hat{a}$ & $\begin{array}{c}m \\
\infty \\
\infty\end{array}$ & $\underset{\sim}{\stackrel{m}{\sim}}$ \\
\hline $\begin{array}{r}\text { ग!шеләЈ } \\
\text { (рәzе|б) длемәрелІ }\end{array}$ & $\begin{array}{l}m \\
\infty \\
\sim \\
\sim\end{array}$ & $\bar{\infty}$ & $\approx$ & जे & 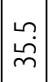 & 1 & I & ลें & 1 & $\mid \begin{array}{l}0 \\
-\end{array}$ & 1 & 1 & I & $\stackrel{0}{-}$ & 1 & 1 & 1 & $\begin{array}{c}\nabla \\
\infty \\
\infty\end{array}$ & I & I & 1 & $\underset{\infty}{\infty}$ & 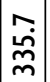 \\
\hline 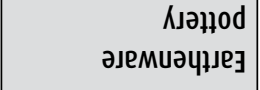 & $\begin{array}{l}- \\
\infty \\
\infty \\
m\end{array}$ & $\underset{\mathbb{Z}}{\mathbb{N}}$ & $\stackrel{2}{\frac{1}{2}}$ & $\stackrel{\text { 능 }}{=}$ & m. & $\stackrel{m}{\sim}$ & 1 & 官 & 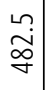 & $\begin{array}{l}\infty \\
\dot{8} \\
\stackrel{D}{2}\end{array}$ & 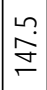 & $\begin{array}{l}0 \\
\vdots \\
\vdots\end{array}$ & $\check{\sigma}$ & $\mid \begin{array}{c}n \\
\stackrel{n}{\infty} \\
\infty\end{array}$ & 1 & $\left|\begin{array}{l}0 \\
\infty\end{array}\right|$ & $\frac{m}{m}$ & $\frac{\nabla}{\dot{m}}$ & $\frac{\infty}{m}$ & 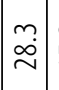 & 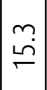 & 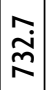 & 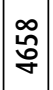 \\
\hline |ел0) & $\underset{\dot{\sim}}{\sim}$ & 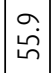 & $\begin{array}{l}\infty \\
\dot{\alpha} \\
\end{array}$ & $\stackrel{m}{\grave{N}}$ & 1 & 1 & Ñ & à & $\stackrel{\sim}{\sim}$ & $\hat{\tilde{m}}$ & $\tilde{0}$ & 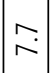 & 1 & màn & 1 & 1 & 1 & $\begin{array}{l}\infty \\
\dot{\sim} \\
\end{array}$ & $m$ & ' & 1 & 市 & $\mid \begin{array}{l}\infty \\
\dot{\delta} \\
\end{array}$ \\
\hline 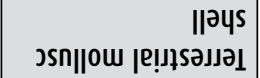 & $\stackrel{\nabla}{m}$ & 1 & $\frac{9}{n}$ & $\stackrel{\vec{\sigma}}{\vec{\sigma}}$ & ' & 1 & $\begin{array}{l}0 \\
0 \\
0\end{array}$ & ڤ̊. & ○्. & $\stackrel{\sim}{\stackrel{2}{=}}$ & m & $\stackrel{\sim}{\sim}$ & $\hat{m}$ & $\stackrel{\substack{\vec{m} \\
m}}{\mid}$ & 1 & $\frac{a}{\dot{m}}$ & $\begin{array}{c}\sim \\
\infty \\
\infty \\
\infty\end{array}$ & $\underset{\dot{f}}{\dot{f}}$ & $\mid \begin{array}{l}\infty \\
\dot{\sigma} \\
\dot{\sigma}\end{array}$ & $\stackrel{+}{-}$ & 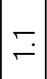 & হ̇. & 芦 \\
\hline 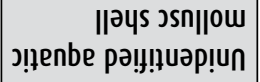 & $\underset{\infty}{\sim}$ & $\widetilde{\sigma}$ & $\begin{array}{l}0 \\
0 \\
\infty \\
\infty\end{array}$ & $\stackrel{\sim}{\stackrel{\sim}{m}}$ & $\stackrel{\sim}{\dot{\sigma}}$ & $\ddot{0}$ & & $\underset{\grave{n}}{\check{N}}$ & $\stackrel{n}{\pi}$ & 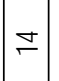 & $\begin{array}{l}m \\
0 \\
r\end{array}$ & 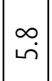 & $a$ & 占 & 1 & बे. & 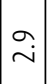 & 芯 & $\stackrel{0}{0}$ & 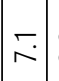 & $\stackrel{m}{\sim}$ & $\bar{c}$ & 岁 \\
\hline 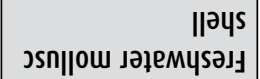 & $\begin{array}{l}0 \\
0 \\
\end{array}$ & $\begin{array}{l}0 \\
0\end{array}$ & $\nabla$ & $\hat{\sim}$ & 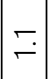 & $\stackrel{m}{-}$ & $\stackrel{+}{0}$ & 응 & 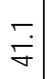 & 5 & $m$ & $\stackrel{\infty}{\sim}$ & 1 & ָิ & 1 & $\dot{0}$ & $\infty$ & $\bar{m}$ & $\mid \begin{array}{l}\infty \\
0 \\
0\end{array}$ & $\stackrel{\sim}{\sim}$ & 1 & $\begin{array}{l}\infty \\
\dot{0} \\
\stackrel{1}{n}\end{array}$ & 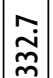 \\
\hline 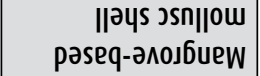 & $\neq$ & 1 & I & 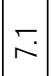 & 1 & 1 & I & $\underset{\sim}{\dot{J}}$ & 1 & $\begin{array}{l}m \\
0 \\
0\end{array}$ & $\hat{m}$ & 每 & ' & $\stackrel{\stackrel{\sim}{\sim}}{\underset{\sim}{\tau}}$ & 1 & I & 1 & बi & ナே. & 1 & 1 & $\stackrel{\mathfrak{m}}{\stackrel{\sim}{\sim}}$ & 종 \\
\hline 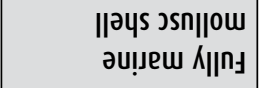 & $\begin{array}{l}\bar{a} \\
\ddot{m}\end{array}$ & ஜ̊ & 弪 & กุ. & $\stackrel{\sim}{\forall}$ & $\stackrel{\sim}{\sim}$ & 1 & 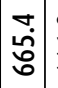 & $\begin{array}{l}\infty \\
\infty \\
\varnothing \\
\end{array}$ & $\begin{array}{l}\stackrel{\sim}{\infty} \\
\stackrel{\infty}{n} \\
\end{array}$ & $\underset{\infty}{-}$ & $\stackrel{m}{\approx}$ & $\stackrel{\infty}{\sim}$ & 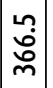 & 1 & 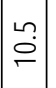 & స̊. & $\underset{\sim}{\Xi}$ & $\stackrel{\sim}{\stackrel{n}{\sim}}$ & t. & \begin{tabular}{l}
$\stackrel{n}{0}$ \\
\hdashline
\end{tabular} & م்َ & 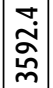 \\
\hline 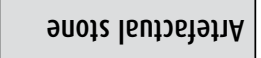 & ナ. & $\stackrel{\infty}{\sim}$ & 1 & 范 & 1 & $\stackrel{\sim}{\longrightarrow}$ & 1 & $\begin{array}{l}\infty \\
\ddot{m} \\
\underline{n}\end{array}$ & $\check{a}$ & $\stackrel{a}{-}$ & 1 & - & I & $\simeq$ & 1 & 1 & 1 & $\begin{array}{l}0 \\
0\end{array}$ & $\stackrel{\sim}{\sim}$ & m. & 1 & $\stackrel{\nabla}{m}$ & 華 \\
\hline 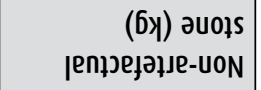 & $\stackrel{\infty}{+}$ & ¿ே. & 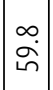 & 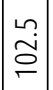 & $\begin{array}{l}\infty \\
0 \\
i \\
i\end{array}$ & $\stackrel{\sim}{\tilde{\gamma}}$ & \begin{tabular}{|c|}
$\sigma$ \\
$\dot{q}$ \\
ஸे
\end{tabular} & \begin{tabular}{|l|}
$m$ \\
$\grave{Q}$ \\
$\dot{\sigma}$
\end{tabular} & $\frac{\hat{\sigma}}{\dot{\sigma}}$ & $\hat{\sim}$ & 官 & \begin{tabular}{|l|}
$\stackrel{n}{n}$ \\
$m$ \\
$m$
\end{tabular} & $\stackrel{\vec{i}}{\stackrel{m}{ }}$ & 灾 & $\begin{array}{l}\infty \\
\dot{J} \\
\end{array}$ & 官 & 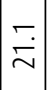 & 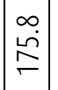 & $\mid \begin{array}{l}0 \\
\dot{g} \\
\dot{g}\end{array}$ & $\frac{m}{2}$ & $\bar{m}$ & $\mid \begin{array}{l}0 \\
\dot{d} \\
\text { qे }\end{array}$ & 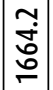 \\
\hline (бү) јшәш!рәs & 官. & $\begin{array}{l}a \\
\dot{f}\end{array}$ & $\stackrel{\vec{\infty}}{\dot{\infty}}$ & $\hat{\grave{\infty}}$ & $\begin{array}{c}0 \\
\stackrel{1}{i} \\
\infty\end{array}$ & $\begin{array}{l}0 \\
\ddot{o} \\
\stackrel{0}{0}\end{array}$ & $\underset{n}{\tilde{b}}$ & 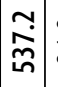 & $\begin{array}{l}\infty \\
\dot{\sim}\end{array}$ & $\stackrel{2}{N}$ & în. & $\begin{array}{l}\infty \\
\vdots \\
0\end{array}$ & $\mid \begin{array}{l}0 \\
\text { ji}\end{array}$ & 官 & 0 & $\stackrel{\sim}{\underset{\sim}{\sim}}$ & $\begin{array}{l}0 \\
\dot{0} \\
-\end{array}$ & $\begin{array}{l}0 \\
\stackrel{2}{\beth}\end{array}$ & $\begin{array}{l}a \\
\dot{b} \\
\infty\end{array}$ & $m$ & $\stackrel{m}{\underset{\sim}{\sim}}$ & $\begin{array}{c}a \\
\infty \\
m \\
m\end{array}$ & 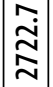 \\
\hline$\overline{\bar{n}}$ & - & $\sim$ & $m$ & $\nabla$ & $\operatorname{Ln}$ & 0 & -1 & \begin{tabular}{l}
0 \\
\multirow{2}{0}{0} \\
0
\end{tabular} & - & $\sim$ & $m$ & $\sigma$ & $\operatorname{Ln}$ & 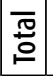 & - & $\sim$ & $m$ & $\sigma$ & $\operatorname{Ln}$ & o & N & $\begin{array}{l}\overline{0} \\
\stackrel{0}{0} \\
0\end{array}$ & \\
\hline 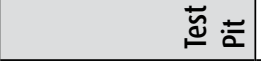 & $\cup$ & $\bullet$ & $\bullet$ & $\bullet$ & $\bullet$ & $\bullet$ & $\bullet$ & $\bullet$ & 0 & O & 0 & 0 & 0 & 0 & -4 & س & -4 & \begin{tabular}{|l|} 
\\
\end{tabular} & \begin{tabular}{|l|} 
\\
\end{tabular} & \begin{tabular}{|l|}
$\mid$ \\
\end{tabular} & ш & w & $\bar{\Sigma}$ \\
\hline
\end{tabular}




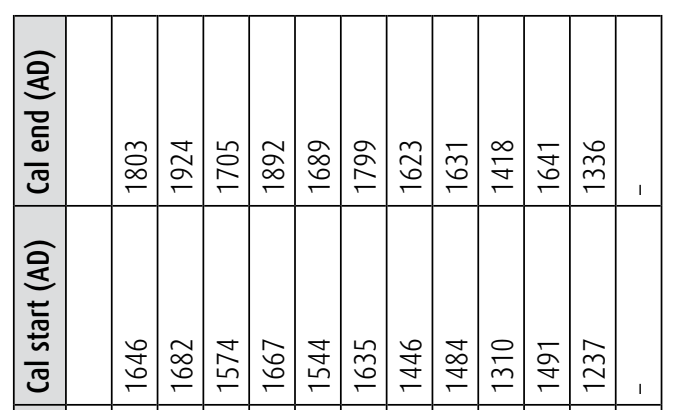

离

矛 $\frac{\overline{0}}{\overline{0}}$

商乒

产

㐫忩

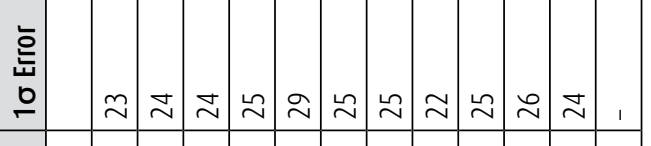

号 牢

융

宽芯

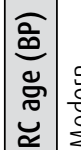

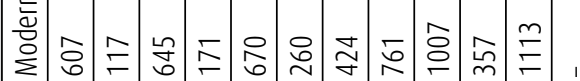

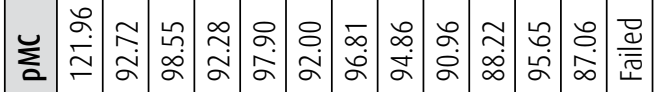

冚 离

흐. 드

峞

穵

음

흘

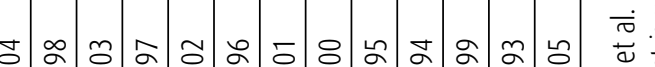

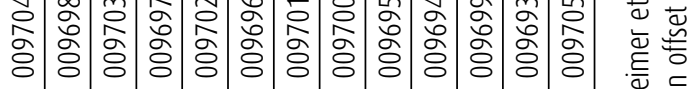

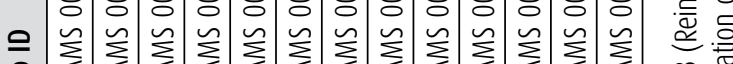

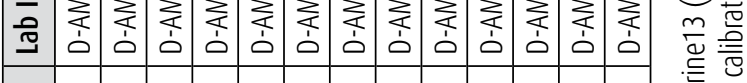

高 首

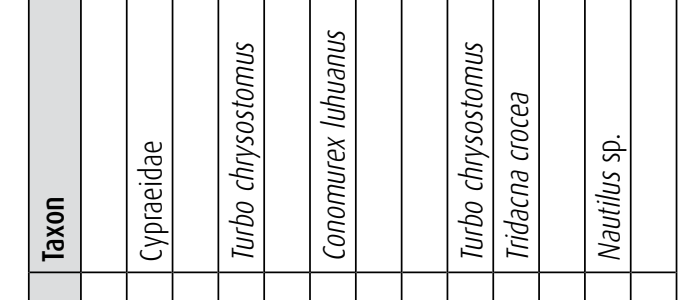

등 밍

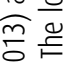

宁

앙름

学

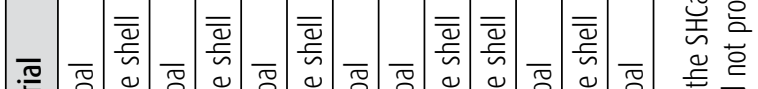

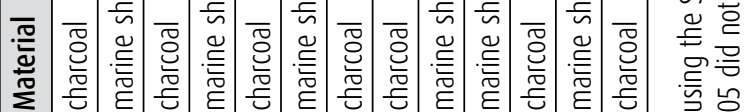

产

总

늘 눙

ㅎㅎㅇ

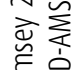

產完

产 部

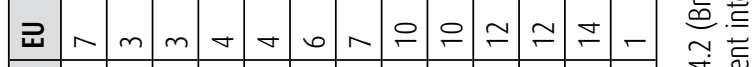

:

远

旁

100 के

gi

亲

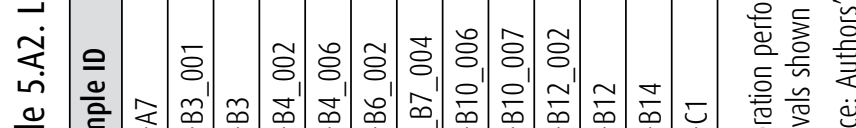

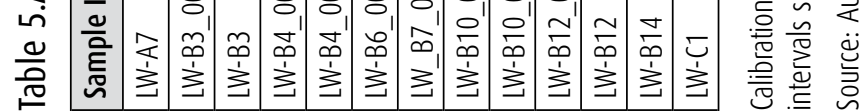


This text is taken from Forts and Fortification in Wallacea: Archaeological and Ethnohistoric Investigations, edited by Sue O'Connor, Andrew McWilliam and Sally Brockwell, published 2020 by ANU Press, The Australian National University, Canberra, Australia.

doi.org/10.22459/TA53.2020.05 